\title{
WOOD MODIFICATION BY HEAT TREATMENT: A REVIEW
}

\author{
Bruno M. Esteves, ${ }^{a^{*}}$ and Helena M. Pereira ${ }^{b}$ \\ Wood heat treatment has increased significantly in the last few years and \\ is still growing as an industrial process to improve some wood properties. \\ The first studies on heat treatment investigated mainly equilibrium mois- \\ ture, dimensional stability, durability and mechanical properties. Mass \\ loss, wettability, wood color, and chemical transformations have been \\ subsequently extensively studied, while recent works focus on quality \\ control, modeling, and study the reasons for the improvements. This \\ review explains the recent interest on the heat treatment of wood and \\ synthesizes the major publications on this subject on wood properties, \\ chemical changes, wood uses, and quality control.
}

Keywords: Chemical changes; Color; Dimensional stability; Durability; Equilibrium moisture; Heat treatment; Mass loss; Mechanical properties; Quality control; Wettability

a: Centre of Studies in Education, Technologies and Health, School of Technology of Viseu, Polytechnic Institute of Viseu, Campus Politécnico Repeses, 3504-510, Viseu, Portugal b: Forest Research Centre, School of Agronomy, Technical University of Lisbon, Portugal; *Corresponding author:

bruno@demad.estv.ipv.pt

\section{INTRODUCTION}

Wood modification can be defined has a process that improves the properties of wood, producing a new material that when disposed at the end of the product life cycle doesn't present an environmental hazard any greater than unmodified wood (Hill 2006). The use of heat treatments to modify the properties of the wood is not new. Even in 1920, Tiemann showed that the drying at high temperatures decreased the equilibrium moisture and the consequent swelling of wood. Kollmann (1936) used high temperatures and densification by hot-press and called this process "Lignostone". According to Morsig (2000) a similar product of laminated compressed wood was marketed in Germany under the name "Lignifol". In 1937, Stamm and Hansen reported that equilibrium moisture, swelling, and shrinking of wood decreased with heating in several gases. In the USA Seborg et al. (1945) created a similar product which they called "Staypack". Stamm et al. (1946) reported a heat-treatment to improve wood dimensional stability without densification and called the process "Staybwood". None of these products had much success in the market, probably due to the availability of high quality wood. Nevertheless, heat treatment was not completely forgotten, and several studies were presented some years later by Seborg et al. (1953), Kollmann and Schneider (1963), Kollmann and Fengel (1965), Noack (1969), Fengel (1966a,b), D'Jakonov and Konepleva (1967), Nikolov and Encev (1967), Burmester (1973; 1975), Rusche (1973 a, b), Giebeler (1983), and Hillis (1984).

More recently the interest in heat treatment processes has been renewed. According to Boonstra (2008) this renewed interest is due to the declining production of durable 
timber, to the increasing demand for sustainable building materials, to the deforestation of especially sub-topical forests, and to the increased introduction of governmental restrictive regulations reducing the use of toxic chemicals. Mainly five different commercial treatments emerged, one in Finland (Thermowood), one in Holland (Plato Wood), one in Germany (OHT-Oil Heat Treatment), and two in France (Bois Perdure and Rectification). New heat treatment processes are also emerging in other countries, such as Denmark (WTT) and Austria (Huber Holz). Some of these processes are in installation, and others are already in full production. Several wood species are used, with different process conditions, depending on species and the final use of the product. All of the processes use sawn wood and treatment temperatures between $160^{\circ} \mathrm{C}$ and $260^{\circ} \mathrm{C}$, but they differ in terms of process conditions, such as the presence of a shielding gas such as nitrogen or steam, humid or dry processes, use of oils, etc. (Militz 2002).

The process named Thermowood, patented by Viitaniemi et al. (1997), is probably the most successful in Europe. According to Boonstra (2008) the total heattreated timber produced in 2007 in Europe amounted to $130,800 \mathrm{~m}^{3}$, and Thermowood represented about $90 \%$ of that amount. The patent states that the wood should be in a humid atmosphere at temperatures higher than $150^{\circ} \mathrm{C}$ for 2 to 10 hours to reach at least $3 \%$ mass loss. The treatment is made with vapour, with less than 3 to $5 \%$ of oxygen, without pressure, and with an air speed of at least $10 \mathrm{~m} / \mathrm{s}$ (Syrjänen and Kangas 2000). The process begins with a fast increase of oven temperature with heat and vapour up to $100^{\circ} \mathrm{C}$, followed by a gradual increase to $130^{\circ} \mathrm{C}$ until almost zero humidity. Afterwards, the heat treatment is made at temperatures between $185^{\circ} \mathrm{C}$ and $230^{\circ} \mathrm{C}$ for 2 to 3 hours, according to Militz (2002), or between $150-240^{\circ} \mathrm{C}$ for 0.5 to 4 hours, according to Syrjänen and Kangas (2000). In the final phase, the temperature is decreased to $80-90^{\circ} \mathrm{C}$ (Militz 2002). The first factory was created in Mänttä (Finland), but by the end of 2001 there were already eleven factories with the capacity to produce $150,000 \mathrm{~m}^{3}$ of treated wood, and twelve in 2004. According to the Finnish Thermowood Association (AlaViikari 2008) the sales production increased from $18,799 \mathrm{~m}^{3}$ in 2001 to $72,485 \mathrm{~m}^{3}$ in 2007. Most of the wood (92\%) in 2007 was sold in Europe, 19\% in Finland, and 73\% in other European countries. This heat treatment technology has recently been introduced in Quebec, Canada by Ohlin Thermo Tech (Shi et al. 2007).

The process used in Holland, called Plato, uses green wood and has four steps. The first step is called hydrothermolysis, and has the duration of about 4 to 5 hours, at temperatures from $160^{\circ} \mathrm{C}$ to $190^{\circ} \mathrm{C}$ in humid conditions and pressures above atmospheric pressure (Boonstra et al. 1998). In the second step, the wood is dried until about $10 \%$ equilibrium moisture by conventional processes during 3 to 5 days. In the third step, the wood is again heated up to $170^{\circ} \mathrm{C}$ to $190^{\circ} \mathrm{C}$ during $14-16$ hours, but now in dry conditions (Militz 2002). The last step raises the wood equilibrium moisture to normal process conditions. The time of treatment depends on the species, thickness, and shape of the wood pieces, as well as the final use. The heating medium can be hot vapour or heated air (Militz 2002). The wood produced by this method is now being commercialized and produced in a factory from the company Plato International with a production capacity of $15,000 \mathrm{~m}^{3}$ in Arnhem (Holland). In 2007 according to Boostra (2008), $7000 \mathrm{~m}^{3}$ were produced.

In France, there are two different processes for heat treatment (Militz 2002), 
called Rectification and Bois Perdure. In the Rectification process the wood is used with $12 \%$ moisture and is treated in one phase, in an oven, at temperatures of $200^{\circ} \mathrm{C}$ to $240^{\circ} \mathrm{C}$ with nitrogen, guaranteeing a maximum of $2 \%$ oxygen. The rectification process has been industrialized since 1997, and rectified wood is being sold with the trademark Retiwood. Several small companies in France produce treated wood mostly by the Rectification process, but it is difficult to evaluate the amount of treated wood produced due to the lack of information by these companies. The process Bois Perdure uses green wood, which is treated by fast drying with vapour and hot combustion gases produced by the rise in temperature of the wood and re-injected into the combustion chamber at temperatures of about 200 to $240^{\circ} \mathrm{C}$. In $2000 \mathrm{PCI}$ Industry purchased the intellectual property rights to the Perdure technology and in 2003 due to a partnership a treatment plant opened in StAmbroise (Québec) and another in Cacouna (Québec). In 2005 the Kisis Technologies plant opened in Dolbeau (Québec).

The process used in Germany is quite different, because it uses oil at high temperatures. In this OHT process, hot oil is introduced in a closed vessel with green wood, and the treatment lasts about 2 to 4 hours with 18 hours in total, including the heating and cooling phases. The oil promotes a good heating and limits the oxygen, but the wood absorbs a great amount of oil corresponding to a mass increase of about 50$70 \%$ (Sailer et al. 2000; Rapp et al. 2001), which can be a disadvantage. The process uses linseed oil, which has an unpleasant smell (Militz 2002). Nowadays there is one factory in Germany, property of the company Menz Holz, in Reulbach, working since August 2000. According to Boonstra (2008) there are three companies in Germany producing OHT wood: The Company Menz holz produced $800 \mathrm{~m}^{3}$ in 2007, while Thermoholz produced $4000 \mathrm{~m}^{3}$. The Bad Essen plant (Hagensieker) has the capacity to produce 10000 $\mathrm{m}^{3}$ of treated wood but in 2007 was not operational.

\section{MASS LOSS}

Mass loss of wood is one of the most important features in heat treatment and is commonly referred to as an indication of quality. Several authors studied mass loss with heat treatment and concluded that it depends on wood species, heating medium, temperature, and treatment time (Fig. 1). Most of the data are difficult to compare because different treatment processes, times and temperatures of treatment, species, and initial moisture contents were used. For instance, Zaman et al. (2000), with Pinus sylvestris and Betula pendula treated between $200^{\circ} \mathrm{C}$ and $230^{\circ} \mathrm{C}$ during $4 \mathrm{~h}$ and $8 \mathrm{~h}$, and determined that the mass losses for pine were smaller than for birch: for pine the mass loss varied between $5.7 \%(4 \mathrm{~h})$ and $7.0 \%(8 \mathrm{~h})$ at $205^{\circ} \mathrm{C}$, and between $11.1 \%(4 \mathrm{~h})$ and $15.2 \%(8 \mathrm{~h})$ at $230^{\circ} \mathrm{C}$, and for birch between $6.4 \%(4 \mathrm{~h})$ and $10.2 \%(8 \mathrm{~h})$ at $200^{\circ} \mathrm{C}$ and between $13.5 \%$ (4h) and $15.2 \%(8 \mathrm{~h})$ at $220^{\circ} \mathrm{C}$. Alén et al. (2002) studied the mass loss of spruce wood at $180^{\circ} \mathrm{C}$ and $225^{\circ} \mathrm{C}$ during $4-8 \mathrm{~h}$ and obtained $1.5 \%$ at $180^{\circ} \mathrm{C}(4 \mathrm{~h})$ and $12.5 \%$ at $225^{\circ} \mathrm{C}$ (6h). Esteves et al. (2007b) reported a higher mass loss for a hardwood (Eucalyptus globulus) than for a softwood species (Pinus pinaster) under the same treatment conditions. Mazela et al. (2003) compared the mass losses with the heat treatment in air and in an atmosphere with water vapour, using Pinus sylvestris at $160^{\circ} \mathrm{C}, 190^{\circ} \mathrm{C}$, and 
$220^{\circ} \mathrm{C}$ during $6 \mathrm{~h}$ and $24 \mathrm{~h}$, and verified that mass losses in the presence of air and of water vapour for 6 hours were similar, but with $24 \mathrm{~h}$ the mass losses in air were higher, especially for the wood treated at $190^{\circ} \mathrm{C}$ and $220^{\circ} \mathrm{C}$.

At higher temperatures $\left(260^{\circ} \mathrm{C}\right)$, the mass losses are quite high; Bourgois and Guyonnet (1988) reported a mass loss for maritime pine of $18.5 \%$ in just 15 minutes, reaching $30 \%$ at the end of one hour.

Kim et al. (1998) found good correlations between weight loss (WL) and time of treatment $(\mathrm{P})$ for several temperatures, with equations like $\% \mathrm{WL}=\mathrm{a}-\mathrm{b} \ln (\mathrm{P})$, with $\mathrm{R}^{2}$ between 0.88 and 0.92 , and for MOR (Modulus of rupture) the best equations were of the type $\%$ MOR $=\mathrm{ae}^{-\mathrm{b}(\mathrm{P})}$.

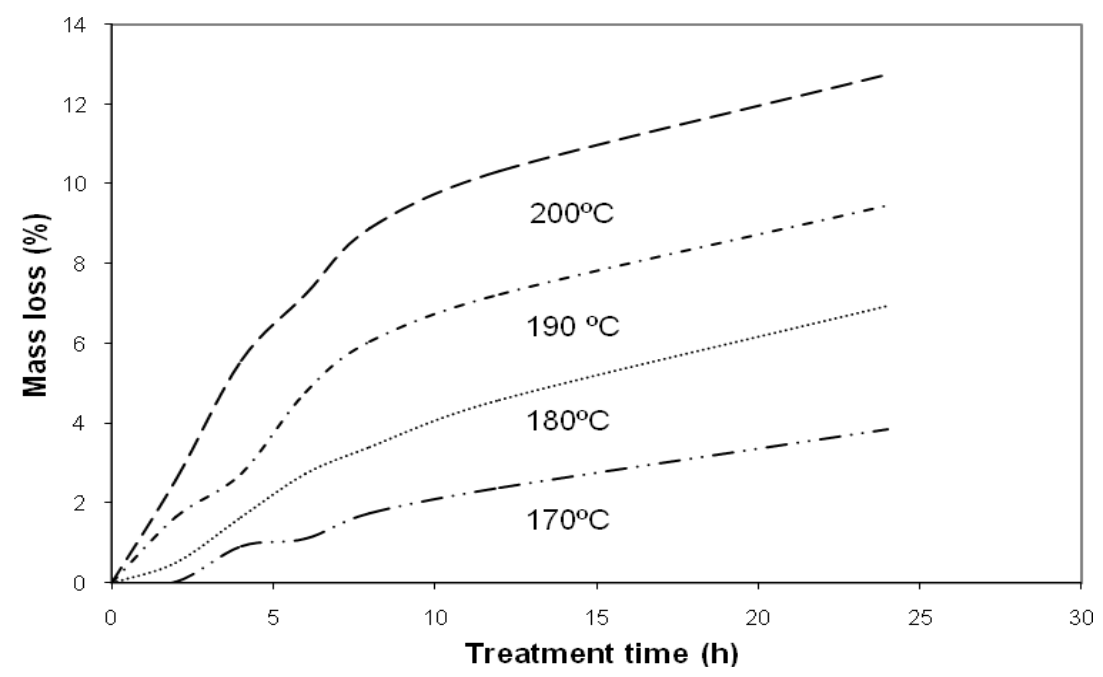

Fig. 1. Wood mass loss vs. heating time for different temperatures. Adapted from Esteves et al. (2008a)

\section{CHEMICAL TRANSFORMATIONS}

The heat treatment of wood changes its chemical composition by degrading cell wall compounds and extractives (Fig 2). The chemical changes due to heating depend on the duration and temperature of the treatment, the temperature being the main factor (Bourgois et al. 1989). For low temperatures between $20-150^{\circ} \mathrm{C}$, the wood dries, beginning with the loss of free water and finishing with bound water. At $180-250^{\circ} \mathrm{C}$, the temperature range commonly used for heat treatments, wood undergoes important chemical transformations, and at temperatures above $250^{\circ} \mathrm{C}$ starts the carbonization processes with formation of $\mathrm{CO}_{2}$ and other pyrolysis products.

The hemicelluloses are the first structural compounds to be thermally affected, even at low temperatures. The degradation starts by deacetylation, and the released acetic acid acts as a depolymerization catalyst that further increases polysaccharide decomposition (Tjeerdsma et al. 1998a; Sivonen et al. 2002; Nuopponen et al. 2004). For example, the content of pentosans of pine wood treated for 7 hours at $130^{\circ} \mathrm{C}$ decreased from $11 \%$ to $9.1 \%$ (Potutkin and Shirayena 1975). Acid catalyzed degradation leads to the formation of formaldehyde, furfural, and other aldehydes (Tjeerdsma et al. 1998a). 
Furfural and hydroxymethylfurfural are degradation products of pentoses and hexoses, respectively (Nuopponen et al. 2004). At the same time hemicelluloses undergo dehydratation reactions with the decrease of hydroxyl groups (Weiland and Guyonnet 2003). The content of carbohydrates decreases with the severity of the treatment and depends on wood species. For instance, the decrease for Betula pendula is higher than for Pinus sylvestris (Zaman et al. 2000). In experiments with Picea abies, Alén et al. (2002) observed that the hemicelluloses degraded more than cellulose, and xylans were the hemicelluloses that were degraded more easily. At higher temperatures $\left(230^{\circ} \mathrm{C}\right)$, xylose and mannose content in wood decreases, and arabinose and galactose disappear (Jämsä and Viitaniemi 2001). Esteves et al. (2008b) determined the content of sugars by acid hydrolysis before and after heat treatment and concluded that hemicelluloses were affected first, as manifested by diminishing yields of xylose, arabinose, galactose, and mannose. Kocaefe et al. (2008a) investigated the chemical modifications of Canadian white birch (Betula papyrifera) and quaking aspen (Populus tremuloides) during heat treatment by FTIR and IGC and concluded that the chemical structure of birch was more affected than aspen due to the higher hemicelluloses content. The results of IGC study suggested that the surfaces of the aspen and birch particles become more basic.

Cellulose is less affected by the heat treatments, probably because of its crystalline nature. According to Bourgois and Guyonnet (1988), the treatment of pine wood at $260^{\circ} \mathrm{C}$, in an atmosphere without oxygen, did not alter cellulose significantly. Similar results were reported by Yildiz et al. (2006). Higher resistance of cellulose in comparison to hemicelluloses was also reported by Esteves et al. (2008b), who observed an increase upon heating of the glucose proportion in hydrolysates due to more selective hemicellulose degradation. Cellulose crystallinity increases due to degradation of amorphous cellulose, as reported earlier, resulting in an decreased accessibility of hydroxyl groups to water molecules (Wikberg and Maunu 2004; Bhuiyan and Hirai 2005; Boonstra and Tjeerdsma 2006), which contributes to a decrease of equilibrium moisture content, in addition to the major effect caused by the degradation of hemicelluloses.

Lignin of Pinus pinaster increased from $28 \%$ to $41 \%, 54 \%$, and $84 \%$, respectively for $0.5,1$, and 4 hours at $260^{\circ} \mathrm{C}$ (Bourgois and Guyonnet 1988). The heat-treated wood of spruce, fir, and poplar had a higher content of lignin than untreated wood and a smaller content of hemicelluloses (Dirol and Guyonnet 1993). For Scots pine and birch treated at temperatures between $205^{\circ} \mathrm{C}$ and $230^{\circ} \mathrm{C}$ during 4 and 8 hours, the lignin content increased from $24.5 \%$ to $38.7 \%$ and from $21.8 \%$ to $35.8 \%$ respectively (Zaman et al. 2000 ). Similar results were reported by Esteves et al. (2008b). It should be noted that the lignin determined using the standard methods in heat-treated wood samples is probably not a pure lignin, since several authors suggested polycondensation reactions with other cell wall components, resulting in further cross-linking, contribute to the increase in apparent lignin content (Tjeerdsma and Militz 2005; Boonstra and Tjeerdsma 2006; Esteves et al. 2008b).

Despite the increase on the percentage of lignin there are also indications that lignin starts to degrade in the beginning of the treatment but at a lower rate than polysaccharides, as reported by some authors (Windeisen et al. 2007; Esteves et al. 2008b). Kotilainen et al. (2000) studied the chemical changes due to the heat treatment in Pinus sylvestris and Picea abies by FTIR and concluded that there was an increase of 
carbonyl groups in lignin. Similar results were reported by Tjeerdsma and Militz (2005), who analysed the holocellulose and lignin of Fagus sylvatica and Pinus sylvestris heattreated wood and concluded that this increase could only be due to lignin. The cleavage of the ether linkages, especially $\beta-\mathrm{O}-4$, leads to the formation of free phenolic hydroxyl groups and $\alpha$ - and $\beta$-carbonyl groups (Nuopponen et al. 2004), which are responsible for cross-linking via formation of methylenic bridges (Tjeerdsma et al. 1998a; Nuupponen et al. 2004; Wikberg and Maunu 2004; Tjeerdsma and Militz 2005). The methoxyl content decreases and the new reactive sites on the aromatic ring can lead to further condensation reactions (Wikberg and Maunu 2004).

Most of the extractives disappear or degrade during the heat treatment, especially the most volatile, but new compounds that can be extracted from wood appear, resulting from the degradation of cell wall structural components. Bourgois et al. (1989) extracted waxes, carbohydrates, tannins, resins, and small amounts of hemicelluloses from Pinus pinaster wood treated at temperatures between 240 and $290^{\circ} \mathrm{C}$. Nuopponen et al. (2003) reported that fats and waxes moved along the axial parenchyma cells to the surface of the sapwood and above $180^{\circ} \mathrm{C}$ were no longer detected on wood. González-Peña et al. (2004) studied the effect of extractives in the degradation of wood during the heat treatment and did not find any significant relationship. Esteves et al. (2008b) reported that, despite the fact that most of the original extractives disappeared from the wood with heat treatment, the extractive content increased substantially with the mass loss, followed by a decrease. The major increase was due to water and ethanol extractives as a result of polysaccharide degradation.

With the heat treatment, there is the formation of a liquid and of a gaseous phase in addition to the solid wood. The liquid phase at temperatures between $200-300^{\circ} \mathrm{C}$ is almost exclusively water and acetic acid with small amounts of formic acid, furfural, and methanol. The acids catalyze the degradation of polysaccharides and reduce their polymerization degree (Militz 2002). This degradation leads to the formation of formaldehyde, furfural, and other aldehydes (Tjeerdsma et al. 1998a).

The hemicelluloses are mainly responsible for the gaseous phase and for a large part of the liquid phase (Bourgois and Guyonnet 1988). The acetic acid comes from thermolysis of the acetyl radicals linked to xylose in xylans; the formic acid is formed from the carboxylic group of the glucoronic chains, and the furfural is from the dehydration of xyloses. This loss of the acetyl radical was confirmed by Sivonen et al. (2002) in NMR studies with Pinus sylvestris treated according to the Finnish method. The same is mentioned by Pétrissans et al. (2003), who observed a decrease of the peaks at 22 and 174 ppm characteristic of carbonyl and methylcarbon groups of the acetyl in the 4-O-methyl$\alpha$-D-glucuronic acid of the arabinoglucuronoxylans and glucuronoxylans. The liquid phase obtained with a heat treatment between $200-260^{\circ} \mathrm{C}$ included $21.5 \%$ of water, $7.5 \%$ of acetic acid, and small amounts of formic acid (5\%), methanol (3.5\%), and some furfural (Dirol and Guyonnet 1993). Alén et al. (2002) reported that the carboxylic acids represented about $90 \%$ of the liquid phase, mostly acetic acid, followed by formic acid, and some phenolic compounds, fats, and resin acids, and small amounts of furans were also identified. Sundqvist et al. (2006) studied the hydrothermal treatment of birch wood and suggested that the major source of formic acid released during the treatment originates from formate esters in the wood and acetic acids from acetate esters in the 
methylglucoronoxylan.

Graf et al. (2003) analyzed the condensable gaseous emissions of a small industrial plant for the heat treatment of spruce and concluded that the released compounds were acetic acid, furfural, dimethylglyoxal, hydroxyacetone, toluene, and several terpenes, especially $\alpha$-pinene. The fraction soluble in acetone included several terpenes: $\alpha$-pinene, limonene, $\beta$-pinene, $\delta$-carene, 4-hydroxy-4-methyl-pentanone, acetic acid, and furfural. The terpenes were released along the whole process, which could allow the reuse of these products. Recent studies by Graf et al. (2005) showed that about $80 \%$ of the products emitted during the heat treatment of six woods (spruce, fir, larch, oak, ash, and robinia) were acetic acid, furfural, and furfural derived compounds, although the softwoods released significant amounts of mono, sesqui, and diterpenes. The recovery of these compounds is not yet profitable due to the low prices of furfural and acetic acid and due to the demand of a high degree of purity of terpenes that would take high investments by the companies that are practicing heat treatment.

According to Mayes and Oksanen (2002), the VOCs emissions of heat-treated wood are less than those of air dried wood, since the emission of terpenes such as pinene, camphene, and limonene during wood drying $\left(1490 \mu \mathrm{g} / \mathrm{m}^{2} \mathrm{~h}\right)$ is higher than for treated pine $\left(110 \mu \mathrm{g} / \mathrm{m}^{2} \mathrm{~h}\right)$. Similar results were reported by Manninen et al. (2002), whose results show that the VOCs emissions of air-dried Scots pine wood were about eight times higher than those of heat-treated wood and consisted of $\alpha$-pinene, 3-carene, hexanal, 2-furan carboxyaldehyde, acetic acid, and 2-propanone. Peters et al. (2008) state that furfural and 5-methylfurfural are the main emission products from treated wood.

In heat-treated wood the percentage of carbon increases and oxygen and hydrogen decrease with the severity of the treatment (Bourgois and Guyonnet 1988), since carbohydrates with more oxygen are more susceptible than others (Alén et al. 2002). Zaman et al. (2000) obtained good correlations between the oxygen content and the mass loss due to heat treatment, which confirms the previous statements. Nguila Inari et al. (2006) studied the chemical composition of treated wood by XPS and concluded that heating at $240^{\circ} \mathrm{C}$ decreased the $\mathrm{O} / \mathrm{C}$ ratio from 0.55 to 0.44 and decreased also the $\mathrm{C} 2$ carbon contribution due to an increase of the $\mathrm{C} 1$ carbon.

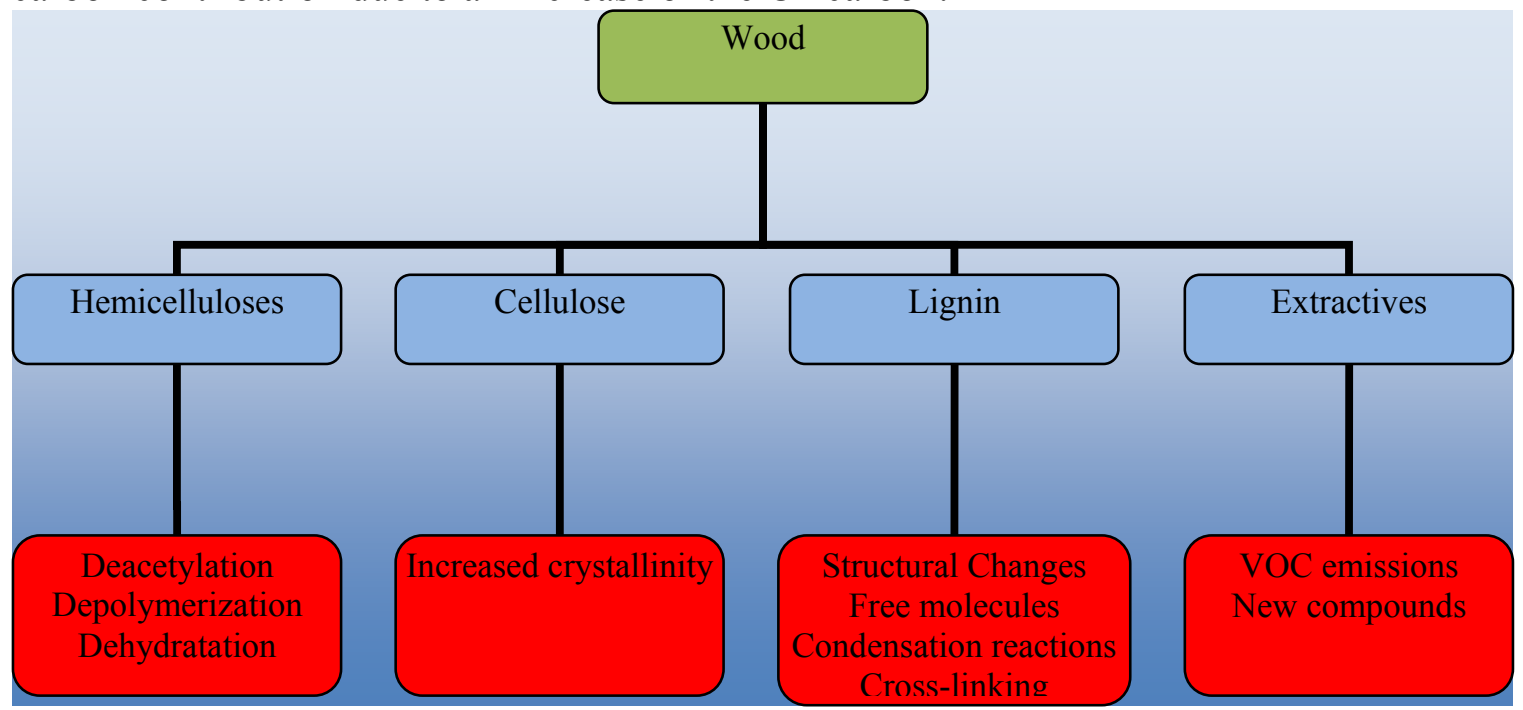

Fig. 2. Chemical changes occurring in the main component of wood due to heat treatment 
Cellulose crystallinity changes with temperature. Up to $200^{\circ} \mathrm{C}$, the crystallinity increases due to the degradation of the less orderly parts (Fengel and Wegener 1989). Sivonen et al. (2002) obtained a clear increase of cellulose crystallinity, confirmed by the increase of the peak at $89 \mathrm{ppm}$ (crystalline cellulose) in the NMR spectra in relation to the peak at $84 \mathrm{ppm}$ (amorphous cellulose) in heat-treated Pinus sylvestris at temperatures between $180-230^{\circ} \mathrm{C}$ for 4 hours. Identical NMR results were obtained by Pétrissans et al. (2003) with poplar, pine, spruce, and beech. However, Dwianto et al. (1996) obtained opposite results in experiments with Cryptomeria japonica, because they mention that cellulose crystallinity decreased with the temperature. In agreement with Roffael and Schaller (1971), the increase of the crystallinity of cellulose between 120 and $160^{\circ} \mathrm{C}$ was followed by a decrease, which can explain the contradictory results. With Pinus densiflora, Taniguchi and Nakato (1966) did not find differences up to $210^{\circ} \mathrm{C}$, after which there was destruction of the supramolecular structure, which ended at $270^{\circ} \mathrm{C}$. The increase of the crystallinity is highly influenced by humidity, as proved by Bhuiyan and Hirai (2000), who obtained the double of the crystallization under high humidity as under oven dry condition. Yildiz and Gümüskaya (2007) agree that cellulose crystallinity increases with the heat treatment and believe that $I_{\alpha}$ (triclinic structure)/ $I_{\beta}$ (monoclinic structure) ratio of cellulose in spruce and beech wood samples changes with thermal modification, since the monoclinic structure is dominant in cellulose crystalline structure.

Mitsui et al. (2008) suggested that the hydroxyl groups in the cellulose degraded in the following order: amorphous, semi-crystalline, and crystalline region.

According to Kubojima et al. (1998), who studied heat-treated American spruce at temperatures between 120 and $200^{\circ} \mathrm{C}$ and with air and nitrogen, the $\mathrm{Cr}$ index (crystallinity of samples treated/untreated) showed some tendency to increase, although with several exceptions. At $200^{\circ} \mathrm{C}$ it increased initially, but it dropped significantly soon after. The length of the crystallites seemed to increase in an initial phase and later on stayed constant, except at $200^{\circ} \mathrm{C}$ in air, where it increased initially and decreased afterwards.

\section{ANATOMICAL EFFECTS}

Fengel and Wegener (1989) analyzed heat-treated spruce wood at $150^{\circ} \mathrm{C}$ by electron microscopy and observed some cracks between the S1 and S2 layers and in the corners of the cells. A similar behaviour was observed with birch and beech wood subjected to a hydrothermal treatment at $120-160^{\circ} \mathrm{C}$ (Filló and Peres 1970; Gromov et al. 1972). Fengel (1966b) found cracks in the middle lamella and in the S1 layer in spruce wood at temperatures from 180 to $200^{\circ} \mathrm{C}$. In addition to the cracks in the cell walls there were also visible changes in the pits, as well as dissolved substances deposited in the torus pits. Gosselink et al. (2004) reported that the heat treatment of Scots pine at $275^{\circ} \mathrm{C}$ for 15 minutes resulted in a more open structure of wood and increased significantly the size and number of pores. According to Boonstra et al. (2006a) heat treatment affects the anatomical structure of wood but the effects depend on the wood species and on the process conditions used. Softwood species were the most susceptible to tangential cracks in the latewood section, especially wood with narrow annual rings and/or an abrupt 
transition between earlywood and latewood. In treated pine species the parenchyma cells in the rays and epithelial cells around resin canals in the sapwood were damaged. These authors also found radial cracks on Norway spruce, which they believe is due to the large stresses on wood structure during heat treatment. Boonstra et al. (2006b) studied the microstructural and physical aspects of heat-treated hardwood and concluded that species like beech and poplar were sensitive to collapse of vessels and some deformation on the libriform fibres near the vessels, while treated beech and birch had some radial cracks near the rays. The broken cell walls perpendicular to the fibre direction, resulting in transverse ruptures, contribute according to Boostra et al. $(2006 \mathrm{a}, \mathrm{b})$ to the abrupt fracture in treated wood bending tests.

Hietala et al. (2002) showed that the dimension of the wood pores increased with heat treatment, perhaps due to the removal of cellular wall components, but they did not find great differences between the dimensions of the cells. Andersson et al. (2005) state that no marked changes in the microfibril angle distribution were observed in X-ray scattering of thermally treated Scots pine. They also mention that the porosity of the cell wall increased. Abe and Yamamoto (2006) investigated the mechanical interactions and associations between cellulose microfibrils (CMF) and the matrix substance, and concluded that the transverse expansion of CMFs observed after hydrothermal treatment and subsequent drying suggests that the matrix substance compresses the CMFs transversely under green conditions. However, as the heat treatment breaks or weakens the association of the CMFs and the matrix substance, under hydrothermal treatment and drying at high temperature the matrix substance cannot compress the CMFs in the direction of the chain.

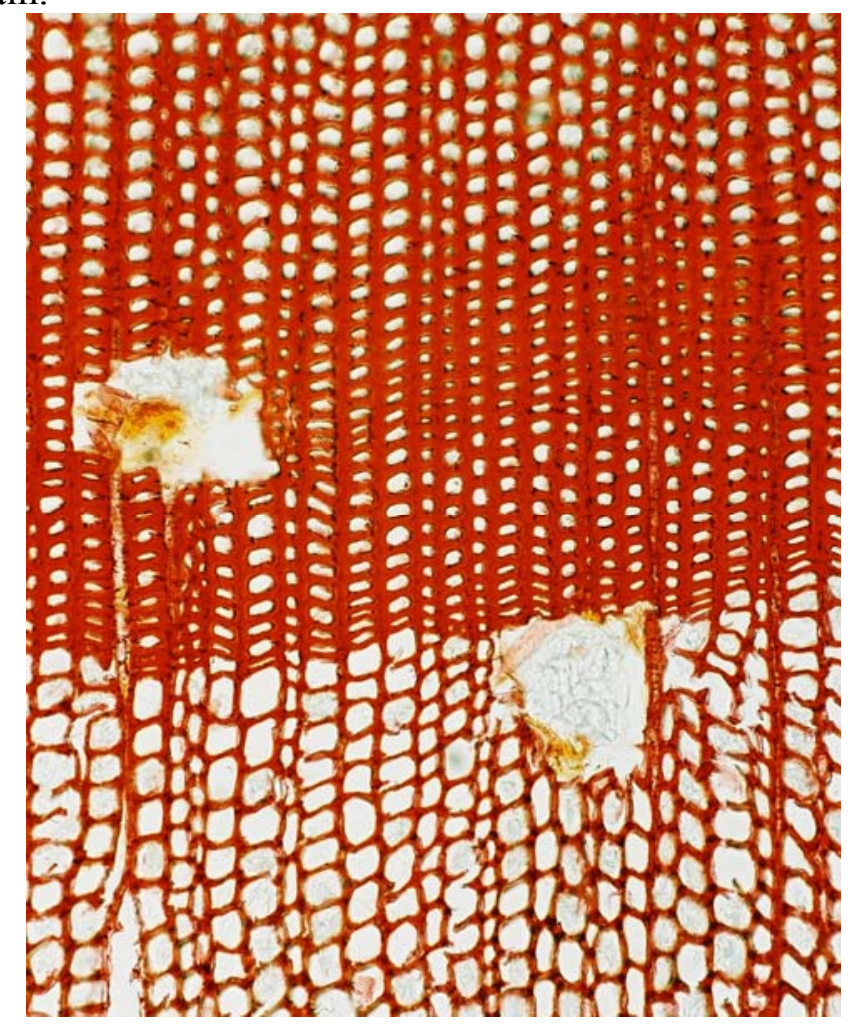

Fig. 3. Heat-treated pine wood cross section. Adapted from Esteves (2006) 


\section{EQUILIBRIUM MOISTURE}

The main effect of the heat treatment is the decrease in equilibrium moisture content. The reduction was already reported in 1920 by Tiemann, who showed that the drying at high temperatures decreased the equilibrium moisture of wood and consequently its swelling and shrinking. This is the basis for all heat treatment processes. As in mass loss, improvement of equilibrium moisture content depends on wood species, temperature, time, and type of treatment.

The minimum temperature necessary to perform a heat treatment is $100^{\circ} \mathrm{C}$ according to some authors. Kollmann and Shneider (1963) carried out tests with beech wood, oak, and pine at temperatures $70^{\circ} \mathrm{C}-200^{\circ} \mathrm{C}$ and $6-24$ hours, and concluded that the absorption of water decreased at temperatures higher than $100^{\circ} \mathrm{C}$, decreasing with the increase in treatment time. The same was confirmed by Nikolov and Encev (1967) and D'Jakonov and Konepleva (1967). However, other authors disagree and believe it depends on the wood species. For example, Kollmann and Fengel (1965) reported that wood degradation begins at $100^{\circ} \mathrm{C}$ for pine but only at $130-150^{\circ} \mathrm{C}$ for oak.

Since there are many variables that influence the increase in equilibrium moisture content, it is difficult to compare most of the reported results. For instance, Tjeerdsma et al. (1998b) reported that with a soft heat treatment the equilibrium moisture of wood (conditioned at 96\%) changed from 30\% (Fagus sylvatica) and 28\% (Pinus sylvestris) to about $18 \%$ and, for more severe treatment to $10 \%$. Kamdem et al. (2002) treated spruce and beech wood by the French method (Rectification) at temperatures between $200^{\circ} \mathrm{C}$ and $260^{\circ} \mathrm{C}$ and obtained small reductions of equilibrium moisture: for spruce wood, from $8 \%$ to $7 \%$, at $66 \%$ relative humidity, from $14 \%$ to $11 \%$ at $86 \%$ relative humidity and from $26 \%$ to $20 \%$ at $100 \%$ relative humidity. The results for beech wood were better, decreasing from $10 \%$ to $5 \%$, from $14.5 \%$ to $8 \%$ and from $21.8 \%$ to $12 \%$, at the relative humidities $66 \%, 86 \%$, and $100 \%$ respectively. Similar results were reported by Epmeier et al. (2001) with spruce wood treated according to the German method (OHT) at $160^{\circ} \mathrm{C}$ and $190^{\circ} \mathrm{C}$ for 4 hours. The equilibrium moisture content of treated spruce wood at $160^{\circ} \mathrm{C}$ changed from $8.7 \%$ to $7.0 \%$ and from $18.9 \%$ to $15.7 \%$ at $30 \%$ and $90 \%$ relative humidity, respectively. The treatment at $190^{\circ} \mathrm{C}$ was more effective, decreasing the equilibrium moisture from $8.1 \%$ to $6.5 \%$ and from $18.6 \%$ to $14.6 \%$ at $30 \%$ and $90 \%$ relative humidity, respectively. The equilibrium moisture content decreases until reaching a minimum value. For example, Esteves et al. $(2007 \mathrm{a}, \mathrm{b})$ reported that the reduction in the wood equilibrium moisture was improved only until 4 to $6 \%$ mass loss and remained approximately constant for higher mass losses.

Some of the treatments use green and others dry wood, but according to Bekhta and Niemz (2003), there is no relationship between the equilibrium moisture decrease and the conditions before the treatment. The difference between the equilibrium moisture of treated and untreated wood remains when changing the air humidity as demonstrated by Edvarsden and Sandland (1999) who subjected heat-treated samples to 5 cycles, alternating between $20^{\circ} \mathrm{C}$ and $85 \%$ relative humidity and $30^{\circ} \mathrm{C}$ and $30 \%$ relative humidity.

Militz (2002) studied the influence of the heat treatment in the adsorption and desorption curves of the wood and concluded that the effect of hysteresis remains, with a 
non-significant increased difference between the curves of adsorption and desorption. Metsä-Kortelainen et al. (2006) showed that heartwood of heat-treated wood absorbed less water than sapwood.

According to Jämsä and Viitaniemi (2001) the reason for the decrease of the equilibrium moisture content is that less water absorbed by the cell walls after the heat treatment as a result of chemical change with a decrease of hydroxyl groups. Other authors point out that the enhanced inaccessibility of hydroxyl groups to water molecules due to the increase of cellulose crystallinity are also significant (Wikberg and Maunu 2004; Bhuiyan and Hirai 2005; Boonstra and Tjeerdsma 2006). The polycondensation reactions in lignin resulting in further cross-linking that might also contribute to the decrease of equilibrium moisture content has also been suggested (Tjeerdsma and Militz 2005; Boonstra and Tjeerdsma 2006; Esteves et al. 2008b).

Repellin and Guyonnet (2005) studied the swelling of heat-treated beech wood by differential scanning calorimetry in relation to chemical composition and concluded that the reduction of wood swelling could not be attributed only to the disappearance of adsorption sites by hemicellulose destruction, but other phenomena such as structural modifications and chemical changes of lignin might also play an important role.

\section{DIMENSIONAL STABILITY}

The decrease of equilibrium moisture of wood due to heat treatments leads to an improvement of wood dimensional stability. One of the first studies to report this improvement was performed by Burmester (1973) who stated that at the optimal pressure and temperature it was possible to reduce the deformation caused by swelling by $75 \%$ in oak, $60 \%$ in beech, $55 \%$ in pine, and 52\% in spruce. Latter studies by Giebeler (1983) mentioned that the swelling decreased between $50 \%$ and $80 \%$ for beech, poplar, pine, spruce, and birch with treatments at temperatures between 180 to $200^{\circ} \mathrm{C}$ in an inert gas atmosphere. In experiments by Dirol and Guyonnet (1993) with spruce, fir, and poplar, the radial and tangential swelling was always smaller in treated wood, decreasing for more severe treatments. Tjeerdsma et al. (1998b) reported that the heat treatment allowed the reduction of swelling (total swelling from dry samples until saturation) from $7.3 \%$ to $5.7 \%$ for Fagus sylvatica and from $4.7 \%$ to $2.8 \%$, for Pinus sylvestris corresponding to efficiencies of $22 \%$ and $40 \%$, respectively.

To quantify the improvement of dimensional stability (Fig. 4) that happens with a certain treatment it is common to use an index of effectiveness designated ASE (Antishrinking efficiency). ASE represents the difference between the swelling of the treated and untreated wood. The swelling is calculated between the dry state and the relative humidity under study. For example, the ASE65\% represents the swelling difference between the treated and untreated wood, from dryness to $65 \%$ relative humidity. The determination of the dimensional stability is usually made in atmospheres with relative humidity ranging from 30 to $90 \%$, similar to the atmospheric conditions found by wood when in use. Yildiz (2002a) with an oven heat treatment in the presence of air, at temperatures of $130^{\circ} \mathrm{C}, 150^{\circ} \mathrm{C}, 180^{\circ} \mathrm{C}$, and $200^{\circ} \mathrm{C}$ and duration of 2,6 , and 10 hours with 
beech wood (Fagus orientalis) reported that the ASE65\% increased with the increase of the temperature and time of treatment, reaching $50 \%$ at $200^{\circ} \mathrm{C}$.

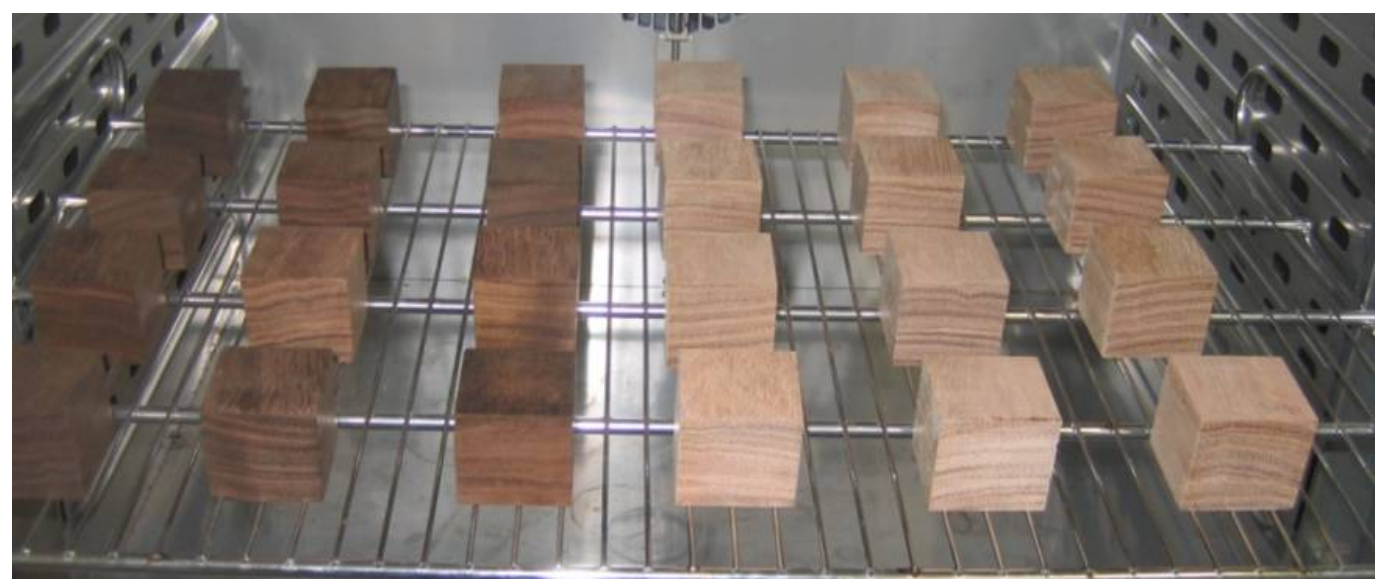

Fig. 4. Determination of wood dimensional stability using a temperature and humidity controlled cabinet. Original photograph

The improvement of dimensional stability depends on the species, as reported by Militz (2002) for beech, Pinus sylvestris, and Pinus radiata. Under the same conditions the radial ASE was $10 \%, 33 \%$, and $35 \%$ and the tangential ASE was $13 \%, 41 \%$, and $40 \%$, respectively.

The increase of dimensional stability is also dependent on the wood direction. For example, the retraction in Pinus sylvestris wood heat-treated in hot oil and hot air at temperatures of $180^{\circ} \mathrm{C}, 200^{\circ} \mathrm{C}$, and $220^{\circ} \mathrm{C}$ decreased more in the tangential direction (up to $2.7 \%$ with air at $220^{\circ} \mathrm{C}$ ) than in the radial direction (up to $1.95 \%$ with air at $220^{\circ} \mathrm{C}$ ). At $220^{\circ} \mathrm{C}$, ASE improved about $40 \%$ for both treatments (Sailer et al. 2000). ASE values are larger for the tangential section. For instance Tjeerdsma et al. (1998b) reported for radial ASE, $10 \%, 13 \%, 11 \%$, and $35 \%$ and for tangential ASE $13 \%, 23 \%, 40 \%$, and $40 \%$, for beech, birch, spruce, and Monterey pine, respectively. Similar results were reported by Esteves et al. (2007a, b; 2008a), who also mentioned that despite the more substantial dimensional stability improvement in the tangential direction, the anisotropy of swelling still remains for the heat-treated wood.

The heat treatment can also be used to improve the dimensional stability of OSB boards, as shown by Goroyias and Hale (2002) for treated wood chips used in the production of OSB at temperatures between $200^{\circ} \mathrm{C}$ and $260^{\circ} \mathrm{C}$. The swelling decreased for treatments at temperatures higher than $210^{\circ} \mathrm{C}$, reaching an improvement of $60 \%$ for treatments at $230^{\circ} \mathrm{C}$.

The increase in dimensional stability for heat-treated wood is mainly due to the decrease of wood hygroscopicity in view of the chemical changes at high temperatures. Dirol and Guyonnet (1993) reported that the dimensional stability can be the result of the formation of polymers from sugars that are less hygroscopic than the hemicelluloses from which they derive. Tjeerdsma et al. (1998a) noted that one of the probable reasons for the improvement of the dimensional stability is the loss of the methyl radicals of some guaiacylic and siringic units of lignin that lead to an increase of phenolic groups and an increase of the proportion of units with free ortho positions. These chemical changes lead 
to higher lignin reactivity with the formation of several crosslinks, responsible for the increase of dimensional stability. With the increase of crosslinking, the molecule becomes less elastic and the cellulose microfibrils have less possibility to expand and to absorb water, which explains the decrease of the equilibrium moisture and the improvement on the dimensional stability. The increased crosslinking can be confirmed by the increase of the NMR peak at $29 \mathrm{ppm}$, which corresponds to the methylenic bridges $\left(-\mathrm{CH}_{2}\right)$ between phenolic compounds. Weiland and Guyonnet (2003) stated that the reason for the improvement cannot be due to the cross linkages because treated wood shrinks in organic solvents such as pyridine or DMSO, and instead they consider that the reason is given by the destruction of several hydroxyl groups and less affinity with water of the wood. Kamdem et al. (2002) also reported that the improvement could not be exclusively due to cross linkages, since they found identical values for the swelling of beech wood in a basic solution before and after the heat treatment.

\section{DURABILITY}

Most woods are susceptible to rot in atmospheres with high humidity. Heat treatment leads to an improvement in the resistance against several biodegradation processes (Fig 5).

Several authors reported an increased resistance to rot for different wood species and types of rot. For instance, Dirol and Guyonnet (1993) studied the effects of wood heat treatment at temperatures between $200^{\circ} \mathrm{C}$ and $260^{\circ} \mathrm{C}$ of three less durable species (spruce, fir, and poplar) on resistance to several fungi (Coriolus versicolor - white rot, Gloeophyllum trabeum, and Coniophora puteana brown rot). In all the cases, mass loss of treated wood was under $1 \%$, while for untreated samples it was higher than $40 \%$. For the heat treatment of pine (Pinus sylvestris) during $6-24 \mathrm{~h}$ at $160^{\circ} \mathrm{C}, 190^{\circ} \mathrm{C}$ and $220^{\circ} \mathrm{C}$, Mazela et al. (2003) found mass losses smaller than 3\% only for the treatment at $220^{\circ} \mathrm{C}$ and $24 \mathrm{~h}, 1.3 \%$ for Coniophora puteana (39.8\% in control samples $(\mathrm{C})), 1.6 \%$ for Gloeophyllum trabeum (22.0\% (C)), 2.2\% for Poria placenta $(48.5 \%$ (C)), and $3.0 \%$ for Coriolus versicolor (11.6\% (C)). Troya and Navarrete (1994) reported that for treatment of poplar the best association of temperature-time to impart resistance against Serpula lacrymans was $240^{\circ} \mathrm{C}-5 \mathrm{~h}$, although $220^{\circ} \mathrm{C}-15 \mathrm{~h}$ could already be considered adequate. Kim et al. (1998) carried out tests with Pinus radiata at $120^{\circ} \mathrm{C}, 150^{\circ} \mathrm{C}$, and $180^{\circ} \mathrm{C}$ during 6 to 96 hours. In all of the cases there was an improvement in rot resistance (between $35 \%$ to $65 \%$ ), but a performance similar to that obtained with a CCA treatment with $1 \%$ retention $(77 \%)$, was only achieved with a treatment at $120^{\circ} \mathrm{C}$ for more than 500 hours or at $180^{\circ} \mathrm{C}$ and 35 hours for dry samples and 40 hours for green samples. For two bamboo species, Leithoff and Peek (2001) reported that to resist the attack of Coriolus versicolor wood needed a treatment for $120 \mathrm{~min}$ at $220^{\circ} \mathrm{C}$, while $60 \mathrm{~min}$ at $200^{\circ} \mathrm{C}$ were enough for Coniophora puteana.

The durability of wood treated by the Plato process was studied by Tjeerdsma et al. (2000) for Pinus sylvestris, Picea abies, Pinus radiata, and Pseudotsuga menziesii. The resistance to rot increased for soft rot, white rot (Coriolus versicolor), and brown rot (Coniophora puteana), with the best performance in relation to brown rot. According to 
Sailer et al. (2000), the OHT treatment at temperatures of $180^{\circ} \mathrm{C}, 200^{\circ} \mathrm{C}$, and $220^{\circ} \mathrm{C}$ improved the resistance to Coniophora puteana, decreasing the mass loss from $48 \%$ and $40 \%$ to about $11 \%$ and $5.5 \%$ in pine and spruce, respectively. At $200^{\circ} \mathrm{C}$ mass loss for pine was only $2 \%$, and for spruce significant improvements were attained at $220^{\circ} \mathrm{C}$, with $0 \%$ mass loss.

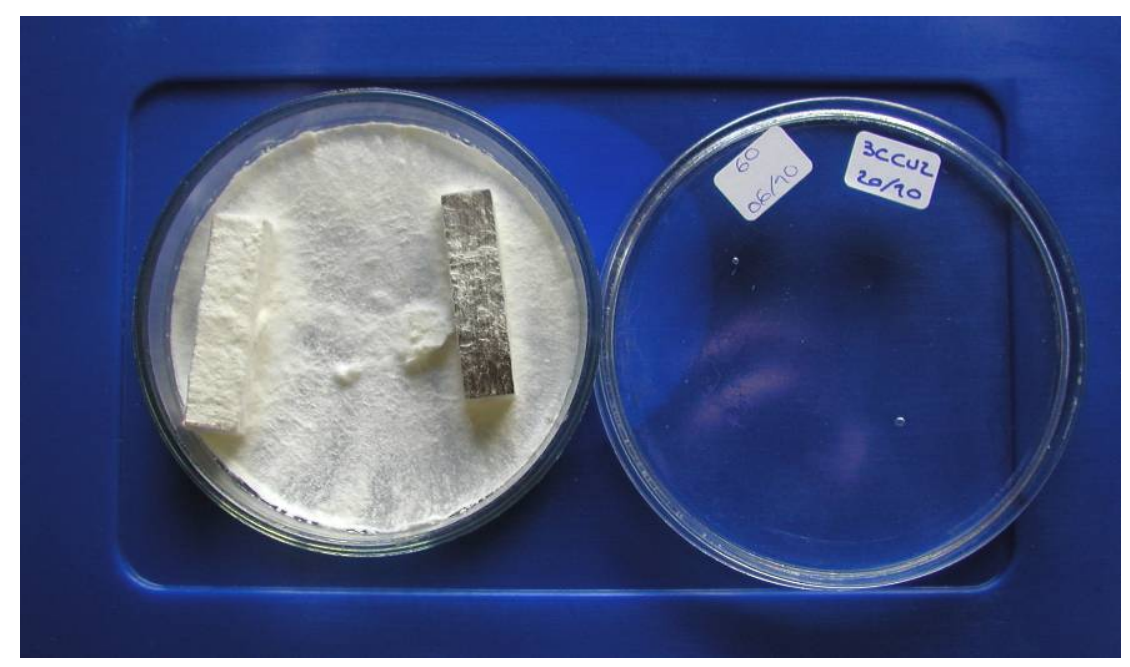

Fig. 5. Heat-treated wood (right sample) resistance to fungal attack in relation to untreated wood (Left sample). Adapted from Esteves (2006)

The resistance to several rot of Pinus pinaster treated by the French Rectification method was studied by Kamdem et al. (2002), who reported that the mass loss was lowered, from $19 \%$ to $2 \%$, with G. trabeum, from $20 \%$ to $8 \%$ with Poria placenta, from $13 \%$ to $6 \%$ with I. lacteus, and from $8 \%$ to $4 \%$ with C. globosum. Boonstra et al. (2007c) reported that heat treatment of radiata pine wood by the Plato process increased the resistance against Coniophora puteana and Poria placenta but did not improve significantly the resistance against Coriolus versicolor. These authors also mention that heat-treated radiata pine and Norway spruce were sensitive to mold grown on the wood surface, which they believe is due to the formation of hemicelluloses degradation products like sugars.

Welzbacher and Rapp (2002) made a comparison between several heat treatment processes. With brown rot (Coriolus versicolor), the wood that showed more resistance was Thermowood (Finland) with a mass loss under 1\%, followed by Plato and OHT woods $(3 \%)$, and finally Rectified wood $(12 \%)$, but all the processes considerably improved wood resistance in relation to untreated wood, which exhibited mass losses of $67 \%$ for spruce and $60 \%$ for Pinus sylvestris. With white rot (Coriolus versicolor) mass losses were 5\% (OHT), 6\% (Plato), 7\% (Rectified), and 8\% (Thermowood) against 35\% and $18 \%$ for untreated spruce and pine, respectively. With Oligoporus placenta, mass losses were higher: 6\% (OHT), 9\% (Plato), 13\% (Rectified), and 15\% (Thermowood) and $27 \%$ and $31 \%$ in untreated spruce and pine. According to EN-350-1 (1994), and using the rot that caused the largest degradation, OHT would be classified as class 2 (durable) and all the others in class 3 (moderately durable). 
Heat treatment doesn't significantly improve the resistance to rot when wood is in contact with soil. The mass loss in contact with soil due to several rot types for pine (Pinus pinaster) treated at temperatures of $200^{\circ} \mathrm{C}$ to $260^{\circ} \mathrm{C}$ was studied by Kamdem et al. (2002), who concluded that in relation to brown rot (G. trabeum) there was a significant improvement from $57 \%$ to $11 \%$ mass loss, while in relation to Poria placenta the mass loss decreased only from $54 \%$ to $47 \%$ and with I. lacteus, from $35 \%$ to $28 \%$.

Kamdem et al. (2000) analyzed the extractives of treated pine and poplar and identified some toxic aromatic compounds derived from phenanthrene and acenapthylene. However the increased resistance to rot was not due to new substances formed during the treatment, because the differences in resistance between wood extracted with water and acetone and unextracted wood were very small (Kamdem et al. 2002). Tjeerdsma et al (2002) reported a good correlation between the hygroscopicity and the increased decay resistance of heat-treated wood. According to Weiland and Guyonnet (2003), the reasons for the improvement of rot resistance are essentially due to two causes. First, some molecules resulting from the heat treatment, such as furfural, can reticulate with lignin, and the fungal enzymatic system does not recognize the substratum and, therefore, does not degrade it. It is also possible that there is an estherification of cellulose due to the acetic acid released by the degradation of hemicelluloses. Second, heat-treated wood has a fibre saturation point lower than untreated wood due to the decrease of the equilibrium moisture, which, by itself, leads to a better resistance against biological degradation. Associated to this fact is the transformation of hemicelluloses, which change from hydrophilic and easily digestible to hydrophobic molecules. Boonstra et al. (2007c) believe that the changes on the external conditions affecting the microenvironment, such as $\mathrm{pH}$ and chemical growth factors, the blocking of reactions of nonenzymatic oxidizing agents and substrate changes affect the decay mechanism of heattreated wood increasing the resistance against fungal attack. Hakkou et al. (2006) reported an important correlation between temperature of treatment and fungal durability, and also that there was insufficient evidence to support the hypothesis of improved decay resistance due to fungicidal compounds or to the hydrophobic character of wood.

Boonstra et al. (2006c) studied the correlation of ${ }^{13} \mathrm{C}-\mathrm{NMR}$ analysis with fungal decay tests and observed that the attack of the brown rot fungi on untreated wood was at C4 but for heat-treated Scots pine was at C6 and for Norway spruce was at C4 and especially C1. Lignin degradation was limited to demethoxylation and low or no aromatic ring opening was observed even after $C$. versicolor exposure. Similar results were reported by Boonstra et al. (2006d) with ground contact tests.

In relation to insects, studies made at CTBA (France) and the University of Kuopio (Finland) showed that there is an increase of resistance against Hylotrupes bajulus, Lyctus brunneus, and Annobium punctatum (Militz 2002). Nunes et al. (2004) studied the resistance to termite of the species Reticulitermes grassei with wood treated by the German method (OHT) and concluded that despite the slightly higher mortality of termites in treated samples and smaller mass loss, the differences were not significant (Fig 6). When treated and untreated wood samples were side by side, termites preferred untreated wood. In relation to marine borers and in accordance to Westin et al (2006) who treated Scots pine wood by several modification processes there is no significant increased resistance. 


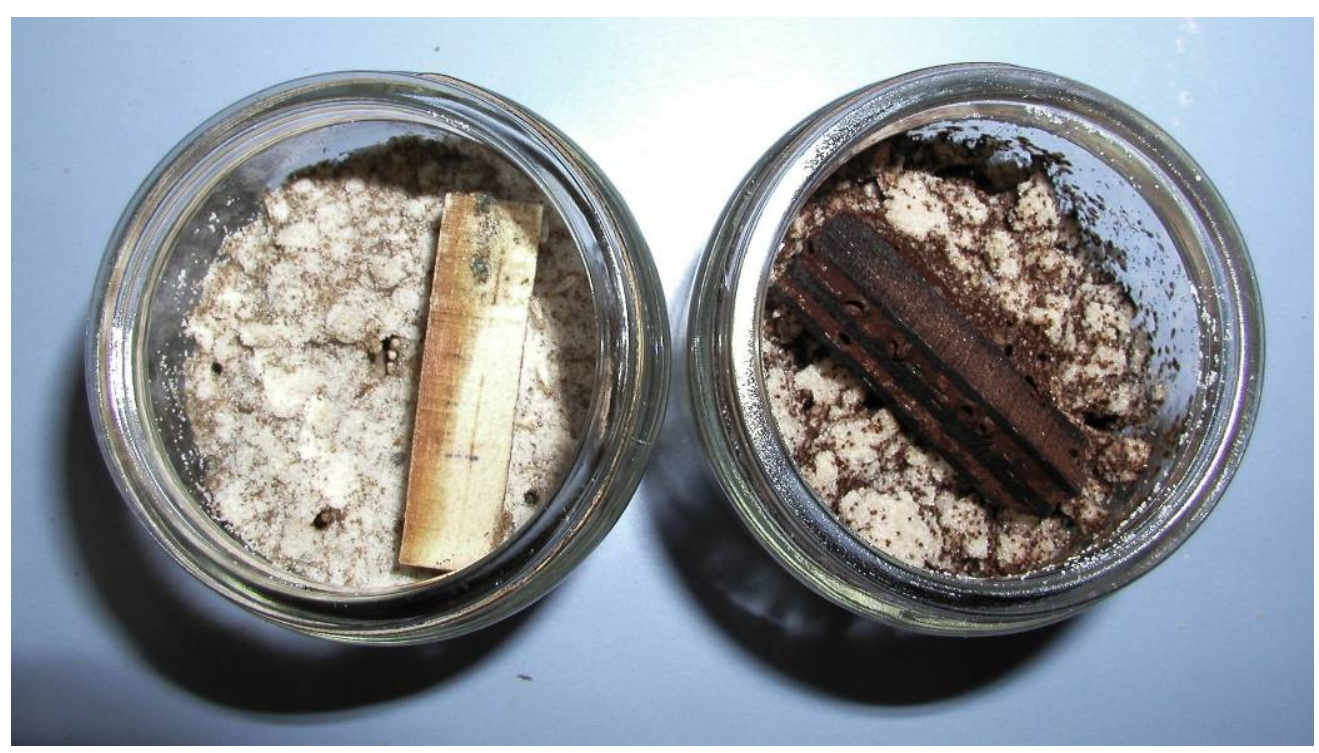

Fig. 6. Termite attack on untreated (on the left) and heat-treated wood (on the right). Adapted from Esteves (2006).

\section{MECHANICAL PROPERTIES}

One of the main heat-treated wood limitations is the decrease of mechanical strength, making this wood unsuitable for most structural applications. The mechanical properties can be determined by static or dynamic tests, but static bending is one of the most used properties to reflect wood behaviour. The load-displacement curve (Fig. 7) in 3-point static bending essays (Fig 8) can be used to determine the modulus of rupture (MOR) and the apparent modulus of elasticity (MOE), which is slightly different from the true modulus of elasticity (ME) that can be obtained in a 4 points assay. When the modulus of elasticity is determined in traction or compression tests, it is usually called the Young modulus.

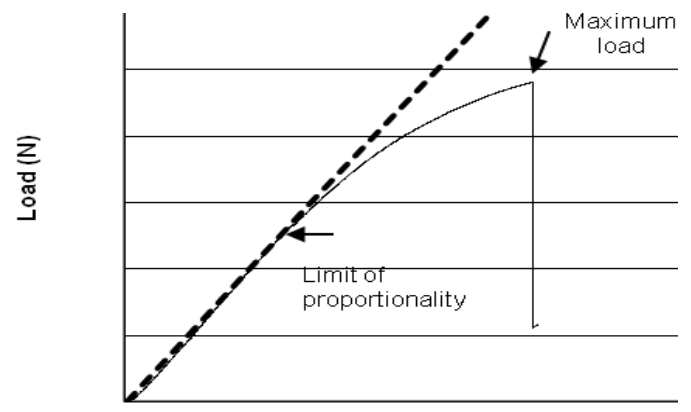

Deflection (mm)

Fig. 7. Typical load deflection curve for heat-treated wood. Adapted from Esteves (2006) 
Two of the most affected mechanical properties by the heat treatment are the resistance to bending in static (MOR) and dynamic tests (impact bending). The reduction depends on wood species and process conditions. The modulus of elasticity seems to increase for softer treatments and decrease for more severe treatments. Results reported by Esteves et al. (2007b) with steam heat-treated pine wood (Pinus pinaster) showed a small increase until about $4 \%$ mass loss, followed by a decrease for higher mass losses. With the same treatment conditions, heating time, and temperature, the reduction of MOE was higher for the treatment in air, and relationship prevailed also when comparing at constant mass loss.

The first tests made by Stamm et al. (1946) showed that heat treatment between $160^{\circ} \mathrm{C}$ and $280^{\circ} \mathrm{C}$ decreased the bending strength (MOR) by about $20 \%$ for a $40 \%$ ASE. Inoue et al. (1993) reported a decrease on MOR for Cryptomeria japonica of $80 \%, 45 \%$, and $20 \%$ with treatments during 8 hours at $220^{\circ} \mathrm{C}, 200^{\circ} \mathrm{C}$, and $180^{\circ} \mathrm{C}$, respectively. MOE increased slightly for wood treated at $180^{\circ} \mathrm{C}$ and $200^{\circ} \mathrm{C}$, decreasing afterwards, reaching a $10 \%$ decrease after 20 hours at $180^{\circ} \mathrm{C}$ and 8 hours at $200^{\circ} \mathrm{C}$. With the treatment at $220^{\circ} \mathrm{C}$, MOE decreased drastically about $60 \%$ in only 7 hours. According to Bengtsson et al. (2002) the decrease of bending strength was, on average, $50 \%$ for spruce and $47 \%$ for Scots pine after treatment at $220^{\circ} \mathrm{C}$; the untreated woods had a bending strength of 24 $\mathrm{MPa}$, which was reduced to $8 \mathrm{MPa}$ in treated spruce and $11 \mathrm{MPa}$ in treated pine. The modulus of elasticity (ME) decreased only about 3.5\%.

In static bending tests (Fig 8) with Pinus radiata wood treated at $120^{\circ} \mathrm{C}, 150^{\circ} \mathrm{C}$, and $180^{\circ} \mathrm{C}$ during 6 to 96 hours, Kim et al. (1998) showed that there was a close relationship between the decrease of bending properties (MOR, MOE and WML) and the process conditions (time and temperature). The work for the maximum load (WML) suffered an accentuated decrease, while the modulus of elasticity was affected less. Poncsak et al. (2006) conducted research with heat-treated birch and showed a reduction of MOR with increasing treatment temperature, especially above $200^{\circ} \mathrm{C}$. The authors also mention a slight hardness increase. Shi et al (2007) studied the mechanical behaviour of Quebec wood species heat-treated using the Thermowood process and concluded that the modulus of rupture decreased between $0 \%$ and $49 \%$ for heat-treated spruce, pine, fir, and aspen, while for birch the modulus increased slightly $(6 \%)$ after the heat treatment. Heattreated spruce and pine modulus of elasticity decreased between $4 \%$ and $28 \%$; however for fir, aspen, and birch the modulus generally increased. Mburu et al. (2008) with heattreated Grevillea robusta wood found reductions on MOR and MOE reaching about 65\% and 28\%, respectively. Boonstra et al. (2007a) reported small reductions in bending strength of heat-treated Scots pine $(3 \%)$ treated by the Plato process but found higher reduction for heat-treated Norway spruce (31\%).

Kim et al. (1998) found good correlations between MOR and heating period (P). The best equations were of the type $\% \mathrm{MOR}=\mathrm{ae}^{-\mathrm{b}(\mathrm{P})}$ with $\mathrm{R}^{2}$ between 0.78 and 0.95 . However, these equations only yielded good results for small periods of time.

Rusche (1973a, b) made heat treatments with and without oxygen using pine and beech and concluded that the modulus of elasticity decreased significantly for mass losses from 8 to $10 \%$. Similar results were reported by Vital et al. (1983), with Eucalyptus saligna treated at $105-155^{\circ} \mathrm{C}$ for $10-160$ hours. Mitchell (1988) studied heat-treated Pinus taed $a$ at $150^{\circ} \mathrm{C}$ and $1,2,4,8$, and $16 \mathrm{~h}$ with equilibrium moisture of $0 \%, 12 \%$, and green, 
in oxygen, nitrogen and air, and found that the MOE decreased irregularly with the time of treatment, decreasing more for green wood. For the heat treatment in air, MOE decrease was 14 times higher in green than in dry wood. In nitrogen there was no decrease of MOE, while with air the decrease was smaller than with oxygen. Santos (2000) reported for heat-treated Eucalyptus globulus a steep increase of the modulus of elasticity from 15,974 MPa to $27,646 \mathrm{MPa}$, although the time and the temperature of the treatment were not mentioned. Different results were reported by Esteves et al. (2007b) for the same wood treated at temperatures between 180 and $210^{\circ} \mathrm{C}$. They found a slight increase at the beginning of the treatment, followed by a decrease. Sailer et al. (2000) did not find differences in the modulus of elasticity for oil and air heat-treated wood at $180^{\circ} \mathrm{C}, 200^{\circ} \mathrm{C}$, and $220^{\circ} \mathrm{C}$, and only for impact bending that decreased $51 \%$ in the case of oil and $37 \%$ in air. Kamdem et al. (2002) used spruce and beech treated by the French method (Rectified wood) between $200^{\circ} \mathrm{C}$ and $260^{\circ} \mathrm{C}$, and obtained a decrease of $11 \%$ and $20 \%$ for MOE, $8 \%$ and $40 \%$ for MOR, respectively for spruce and beech. Goroyias and Hale (2002) studied the heat treatment of Pinus sylvestris chips for OSB production between $200^{\circ} \mathrm{C}$ and $260^{\circ} \mathrm{C}$ for 20 minutes. MOR did not decrease significantly for $200^{\circ} \mathrm{C}$ and $210^{\circ} \mathrm{C}$, decreased slightly for $220^{\circ} \mathrm{C}, 230^{\circ} \mathrm{C}$, and $240^{\circ} \mathrm{C}$, and decreased significantly for $250^{\circ} \mathrm{C}$ and $260^{\circ} \mathrm{C}$. The variation in MOE was similar with a decrease for temperatures higher than $240^{\circ} \mathrm{C}$.

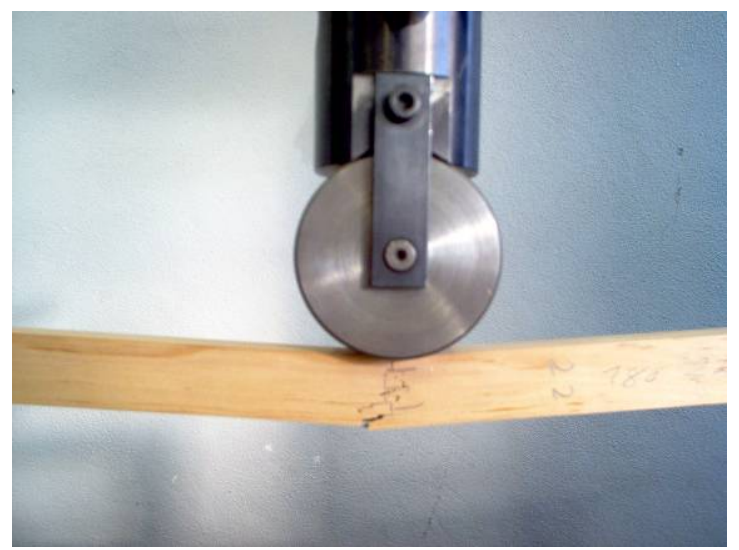

Fig. 8. Determination of static bending strength of a wood specimen. Adapted from Esteves (2006)

Kubojima et al. (1998) made some vibrational studies with Picea sitchensis, and observed that the Young modulus in longitudinal and radial directions increased in the first two hours of treatment and remained constant afterwards for wood treated at $120^{\circ} \mathrm{C}$ and $160^{\circ} \mathrm{C}$. At $200^{\circ} \mathrm{C}$, the Young modulus increased in an initial phase, decreasing after that. The shear modulus in longitudinal and radial directions increased in an initial phase, becoming constant for 120 and $160^{\circ} \mathrm{C}$, while for $200^{\circ} \mathrm{C}$ increased initially and decreased afterwards. The Young modulus increased with the increase of cellulose crystallinity and with the decrease of wood moisture. The effect of crystallinity prevails in the beginning of the treatment but with the continuation of the treatment the heat degradation is dominant, leading to the decrease of the Young modulus.

Kubojima et al. (2000a) reported that the effects of heat treatment were similar in green and dry wood. The same authors (Kubojima et al. 2000b) also reported that the Young modulus and the bending strength increased in the beginning of the treatment, and 
decreased afterwards, more for the treatments in air than in nitrogen. The work needed for rupture decreased steadily with the time of treatment, more in nitrogen than in air. The main factors contributing to the reduction of the work necessary for rupture were viscosity and plasticity, but not elasticity. The impact bending also increased in the beginning, lowering afterwards, more for treatments in air than in nitrogen.

Unsal and Ayrilmis (2005) reported a reduction on the compression resistance parallel to the fibre of heat-treated Turkish river red gum. Korkut et al. (2008a) studied heat-treated Scots pine wood and concluded that compression strength parallel to grain, bending strength, modulus of elasticity in bending, janka-hardness, impact bending strength, and tension strength perpendicular to the grain decreased. Similar results were presented by Korkut et al. (2008b) for Red-bud maple (Acer trautvetteri). Somewhat different results were reported by Boonstra et al. (2007a). These authors found a 28\% increase on compressive strength parallel to the fibre and a slight increase $(8 \%)$ in tangential compressive strength for heat-treated Scots pine by the Plato process. Radial compressive strength however decreased $43 \%$. They also reported a strong decrease in the tensile strength $(39 \%)$ and a small reduction (3\%) of the bending strength (MOR). The Brinell hardness parallel to the grain increased significantly (48\%), whereas the hardness perpendicular to the grain increased slightly $(5 \%)$.

The density of wood treated by the French method (Rectified wood) between $200^{\circ} \mathrm{C}$ and $260^{\circ} \mathrm{C}$ decreased from $447 \mathrm{~kg} / \mathrm{m}^{3}$ to $381 \mathrm{~kg} / \mathrm{m}^{3}$ and from $623 \mathrm{~kg} / \mathrm{m}^{3}$ to 617 $\mathrm{kg} / \mathrm{m}^{3}$ for spruce and beech wood, respectively, corresponding to a decrease of $15 \%$ and $1 \%$. Yildiz (2002b) reported a minor density increase for beech $(2.25 \%)$ and spruce $(1.73 \%)$ woods for treatments at $130^{\circ} \mathrm{C}$ for 2 hours but mentioned that for treatments at higher temperatures $\left(200^{\circ} \mathrm{C}-10\right.$ hours $)$ density decreased $18.37 \%$ and $10.53 \%$ for beech and spruce woods, respectively. Korkut and Guller (2008) conducted research on heattreated red-bud maple (Acer trautvetteri) and confirmed the density decrease. Boonstra et al. (2007a) reported a $10 \%$ and $8.5 \%$ decrease on density for heat-treated Scots pine and Norway spruce, respectively.

Reiterer and Sinn (2002) studied the fracture properties of autoclave heat-treated spruce wood, using the wedge splitting test, and concluded that the resistance against crack initiation was smaller and the energy consumed was higher. The fracture properties of heat-treated wood under nitrogen also decreased, but less than for the wood treated in an autoclave. The brittleness of heat-treated wood was confirmed by the microscopic observation of the fracture surface. Phuong et al. (2007) studied the effects of heat treatment on brittleness of Styrax tonkinensis wood and concluded that the main factor affecting brittleness was the loss of amorphous polysaccharides due to degradation.

Nakano and Miyazaki (2003) studied the variation of the dimension of fractures on the surface of treated wood with the treatment temperature and concluded that they increased steadily up to $250^{\circ} \mathrm{C}$ with a steep increase for higher temperatures.

According to Boonstra et al. (2007b) heat-treated wood can be used in construction if the stresses that occur in construction are taken into account. These authors treated Norway spruce construction wood and obtained a $6 \%$ reduction in bending strength and a $17 \%$ increase on MOE. They also mentioned that only a combination of several defects, such as large knots, enclosed pith, and an abnormal slope of grain, decreases the bending strength and MOE of treated posts, and that the effect of a three-year period of outdoor 
exposure on the strength properties of heat-treated terrace planking is limited.

The reasons for the changes on mechanical properties have been extensively discussed by Boonstra et al. (2007a). The degradation of hemicelluloses has been proposed as the major factor for the loss of mechanical strength, affecting especially bending and tensile strength, but also the crystallization of amorphous cellulose might play an important role. Polycondensation reactions of lignin, resulting in cross-linking, are mentioned as having a positive impact mainly in the longitudinal direction. The differences between the compressive resistance parallel to the fibre (increase) and compressive strength radial (decrease) are attributed to the anisotropy of crystalline cellulose. The lower equilibrium moisture content might affect positively the strength properties of heat-treated wood, but this effect is superseded by the degradation of the chemical compounds. In relation to the density decrease they believe that the degradation of hemiceluloses into volatile products and the evaporation of extractives are the main reasons. A close relationship between hemicelulose content and bending strength was also reported by several authors (Winandy and Lebow 2001, Esteves et al 2008a).

\section{WETTABILITY, WEATHERING, WOOD FINISH AND GLUING}

The wettability of heat-treated wood (Fig 9) decreases with treatments between $130^{\circ} \mathrm{C}$ and $210^{\circ} \mathrm{C}$, with a maximum at about $190^{\circ} \mathrm{C}$, which according to Pecina and Paprzycki (1988) is due to the formation of degradation compounds. In tests with poplar, beech, spruce, and maritime pine at temperatures between $40^{\circ} \mathrm{C}$ and $260^{\circ} \mathrm{C}$ during 8 hours, Hakkou et al. (2003) concluded that the wettability decreased drastically, starting at $135^{\circ} \mathrm{C}$, and increasing slightly afterwards with the temperature increase. No relationship was found between the wettability decrease and the mass loss or extractive content. The same was confirmed by Pétrissans et al. (2003), who suggested that one of the possible reasons for the decrease of wettability could be the increase of cellulose crystallinity. Hakkou et al. (2005) reported that the degradation reactions and the formation of extractives are not the reasons for the wood hydrophobic properties. Studies by ${ }^{13} \mathrm{C}$ CPMAS NMR and FTIR suggest that the wettability change could be due to a modification of the conformational arrangement of wood biopolymers resulting from the loss of residual water or, more probably, from the plasticization of lignin. The wettability change was larger for poplar, followed by pine, spruce, and beech.

Kocaefe et al. (2008b) studied the characteristics of the dynamic wetting of white ash (Fraxinus americana) and soft maple (Acer rubrum) and concluded that the contact angle increased significantly and the advancing contact angles of a water drop were higher for heat-treated than for untreated wood.

For heat treatments above $200^{\circ} \mathrm{C}$, the wood surface becomes hydrophobic and the absorption of glues and varnishes is slower than in untreated wood. The superficial energy of wood is drastically affected by the temperature, and therefore the normal finishes cannot be used with heat-treated wood (Vernois 2000). However there are varnishes that can be adapted to this type of wood. The same happens with glues. Petric et al. (2007) investigated the wettability of oil-heat-treated Scots pine wood with some commercial waterborne systems and concluded that although the hydrophobic character 
increased, exterior waterborne coatings exhibited much better wetting on modified wood.

Fig. 9. Determination of heat-treated wood wettability. Original photograph

The need for special attention in the gluing process of treated wood is not unanimous. Pincelli et al. (2002) studied the influence of the heat treatment between $120^{\circ} \mathrm{C}$ and $180^{\circ} \mathrm{C}$ in the gluing process, using three common glues (phenol-resorcinolformaldehyde, modified polyvinyl acetate, and urea-formaldehyde) and found no significant differences between the treated and untreated wood, with the exception of shearing stress. The wood did not fail in the gluing line, which indicates that these glues can be used with treated wood. In gluing essays with phenol-resorcinol-formaldehyde (PRF) and polyvinyl acetate (PVAc), Bengtsson et al. (2003) reported that the PRF adhesive achieved good results, but PVAc exhibited a lamination percentage (in agreement with the EN 391 norm) that makes it inappropriate to glue treated wood. Sernek et al. (2008) studied the bonding of untreated, intermediate (hydro-thermolysed), and heat-treated wood with melamine-urea-formaldehyde (MUF), phenol-resorcinolformaldehyde (PRF) and polyurethane (PUR) adhesives by the Plato process and concluded that the heat treatment affected the shear strength and the delaminating of the laminated wood depending on the adhesive system used for bonding. Both PUR and MUF adhesives performed better than the PRF adhesive, and better for untreated wood The low $\mathrm{pH}$ (PRF) and wettability (PRF and MUF) of heat-treated wood were proposed as being the main reasons for this difference.

Follrich et al. (2006) studied the effect of thermal treatment on the adhesion between wood and a non-polar thermoplastic polymer on spruce boards and concluded that the initial breaking force and the fracture energy of wood-thermoplastic adhesive assemblies increased significantly with increasing treatment time, while lap-shear strength was unaffected.

Treated wood exposed to weathering for 5 years presented the same fissures as untreated wood, but the acid cure and the acrylic varnishes showed a better behaviour in the treated wood with less density of fissures in the acrylic varnishes (Jämsä et al. 2000). The best systems for wood finish of heat-treated wood were the use of a primary (oil) and an acrylic varnish of aqueous base or an alkydic resin in a solvent base. According to these authors, the better performance of treated wood for longer exposure periods is due 
to its dimensional stability. Nuopponen et al. (2004) reported that heat-treated wood was more resistant to natural weathering mainly because some of its lignin degradation compounds are less leachable than those of untreated wood.

The colour variations of treated wood exposed to ultraviolet radiation were studied by Ayadi et al. (2003) who found that the colour variation $(\Delta \mathrm{E})$ of treated samples after 835 hours of exposition was smaller than the variation for untreated wood: from 18 to 7 , from 28 to 11 , from 25 to 5 and from 26 to 8 respectively for beech, poplar, ash, and maritime pine. The changes were explained by the increase of phenolic groups and lignin stabilization during the heat treatment.

Gerardin et al. (2007) studied the surface free energy of wood, which decreases slightly after heat treatment. According to these authors this is due to the slight modification of Lifshitz-van der Waals component and to the strong reduction on the acid-base component after thermal treatment.

\section{OTHER PROPERTIES AND USES OF TREATED WOOD}

Colour is a very important wood property for the final consumer, and in some cases it is the determining factor for the selection of a specific wood, since the visual decorative point of view is often prevailing. Most wood colour studies quantify the colour by the CIELAB method created by the Commission International de l' Éclairage with a three axes system: lightness $\left(\mathrm{L}^{*}\right)$ from $0 \%$ (black) and 100\% (white), a* from green (-a) to red $(+a)$, and $b^{*}$ from blue $(-b)$ to yellow $(+b)$. Viitaniemi et al. (1997) found good correlations between lightness $\left(\mathrm{L}^{*}\right)$ and treatment temperature for Pinus sylvestris. The samples become darker with the increase in treatment time and temperature (Fig. 10), as reported by several authors (Mitsui et al. 2001; Militz 2002; Bekhta and Niemz 2003; Mitsui et al. 2003, 2004). Esteves et al. (2008c) reported that noticeable colour changes could already be obtained for small mass losses of $2-4 \%$, but the effect depended on the extent of treatment and was related to chemical composition of the heat-treated woods. In air the colour alteration was higher and faster than in steam. The heat-treated woods maintained surface characteristics resulting from their anatomical structure, namely distinction of earlywood/latewood in pinewood and some differences between transverse and radial/tangential sections.

The darker tonality of heat-treated wood is often attributed to the formation of coloured degradation products from hemicelluloses (Sehlstedt-Persson 2003; Sundqvist 2004) and to extractives that seem to participate in the colour formation of heat-treated wood. (McDonald et al. 1997; Sundqvist and Morén 2002). The formation of oxidation products such as quinones is also stated as the reason for colour change (Tjeerdsma et al. 1998a; Mitsui et al. 2001; Bekhta and Niemz 2003). Sehlstedt-Persson (2003) also suggested that the change in colour resulting from hemicellulose degradation might be due to hydrolysis by a reaction similar to a Maillard reaction, which is a well-known process in the food industry. Heat-treated wood has a characteristic smell that is progressively reduced when wood is in use, which might be due to furfural (Militz 2002). 


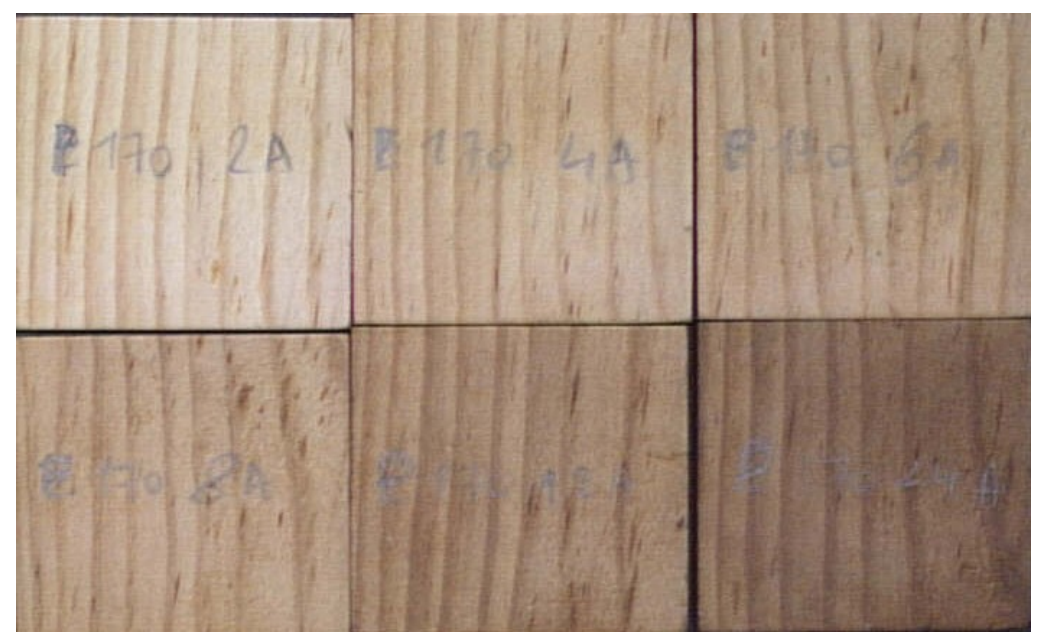

Fig. 10. Darkening of Pinus pinaster wood with heat treatment at $170^{\circ} \mathrm{C}$ during $2-24 \mathrm{~h}$. Adapted from Esteves (2006)

Mass transfer properties in heat-treated poplar wood were determined by Rousset et al. (2004), who concluded that the heat treatment reduced mass diffusivity but did not significantly change wood permeability.

According to Mayes and Oksanen (2002) the thermal conductivity of heat-treated wood is reduced by 20 to $25 \%$ in relation to untreated softwoods, which is an advantage for some applications such as outer doors, cladding, windows, and saunas.

Heat-treated wood has a large application for outdoor use in cladding, decks, garden furniture, and window frames, as well as indoor use for kitchen furniture, parquet, decorative panels, and mainly for the interior of saunas. According to Bengtsson et al. (2002), spruce and Scots pine treated at $220^{\circ} \mathrm{C}$ can be used in decks, cladding, window frames, exterior furniture, stairways and other applications where the physical strength is not very important. For example, for stairways and decks, the most important property is stiffness and not resistance to breakage. Wood treated at these temperatures cannot be used as support beams.

Syrjänen and Kangas (2000) report that the wood species treated by the Finnish method (Thermowood) are essentially: Scots pine (Pinus sylvestris) and spruce (Picea abies), that are more used in the exterior for terraces, fences, garden furniture, doors and windows, and poplar (Populus trembles) and birch (Betula pendula) that are more used in the interior for kitchen furniture, pieces of furniture, parquets, and panels. This treated wood is particularly used in saunas because it possesses a heat transfer coefficient smaller than untreated wood.

\section{QUALITY CONTROL AND MODELING}

The quality of heat-treated wood cannot be measured by the same methods as for untreated wood. Repellin and Guyonnet (2003) studied the use of three non-destructive methods for the quality classification of heat-treated beech wood, mainly mass loss, lightness, and some mechanical parameters such as the Young modulus. Lightness and 
mass loss were the properties that best characterized the wood quality of heat-treated beech, although the results were not good for another species.

Patzelt et al. (2003) suggested that colour could be used as a classification method of treated wood, because it has a significant correlation with mass loss. The same was confirmed by Bekhta and Niemz (2003), who affirmed that colour could be used to foresee the mechanical alterations of treated wood.

Hinterstoisser et al. (2003) proposed that the near infrared (NIR) spectra of the heat-treated wood surface could be used for classification purposes, since the differences were high. These authors observed differences in the NIR spectra of wood for treated spruce at $440 \mathrm{~K}$ for periods from 1.5 hours to 48 hours, and large differences were observed between samples with 18 and 48 hours of treatment. A close relationship between chemical changes and NIR spectra of modified beech wood was reported (Schwanninger et al. 2004). Another quality control method was reported by Rapp et al. (2006) based on high energy multiple impact, which is not affected by weathering or cracks although it has the disadvantage of being a destructive analysis. The CIELAB color measurements were also mentioned as a possible approach for determining treated wood quality (Brischke et al. 2007). Johansson and Moren (2006) believe that color is not suitable as a predictor of strength because color distribution through the thermally treated boards was not homogeneous. These authors concluded that temperature is the most important process parameter, and that the best way of controlling strength loss was to have control over the climate inside the kiln together with a measurement of MOE.

NIR spectroscopy using a fiber probe on the radial surface of the samples was tested for predicting the properties of heat-treated pine (Pinus pinaster) and eucalypt (Eucalyptus globulus) by Esteves and Pereira (2008), and calibration curves were developed for mass loss, equilibrium moisture content, dimensional stability, MOE, bending strength, color CIELAB parameters, and extractives content. The models were in general good, with coefficients of determination ranging between $96-98 \%$ for mass loss, $78-95 \%$ for equilibrium moisture content, 53-78\% for dimensional stability, 47-89\% for MOE, $75-77 \%$ for bending strength and $84-99 \%, 52-96 \%$, and $66-98 \%$ for color parameters L, $a^{*}$, and $b^{*}$, respectively.

In the last few years there has been some study involving modeling of heat-treated wood. Kocaefe et al. (2006) used Luikov's approach for modeling the heat and mass transfer during high temperature treatment of aspen and concluded that the accuracy of the model predictions depends on the accuracy of the thermo-physical properties used in the model, and if the accuracy is good the predictions of the model can approach the experimental results. Younsi et al. (2006a, b) reported a three-dimensional simulation of heat and moisture transfer in wood and concluded that the Luikov number affects both the heat and mass transfer. These authors believe that the governing dimensionless parameters have a considerable influence on the kinetics of the heat and moisture transfer. Younsi et al. (2007) suggested a mathematical model to follow the heat and moisture distribution inside the sample wood during heat treatment by solving NavierStokes equations for the fluid field and multiphase model for the solid. According to the author the model predictions had sufficient accuracy within the range of temperatures considered in the study. 


\section{CONCLUSIONS}

1. The number of heat treating companies and processes are increasing, and commercialization of heat-treated wood is also growing.

2. Heat treatment changes the chemical composition of wood, leading to mass loss.

3. Hemicelluloses are the most affected compounds. The degradation starts by deacetylation, and the released acetic acid acts as a depolymerization catalyst, which further increases polysaccharide decomposition. Acid-catalyzed degradation leads to the formation of formaldehyde, furfural, and other aldehydes. Furfural and hydroxymethylfurfural are degradation products of pentoses and hexoses, respecttively. At the same time hemicelluloses undergo dehydration reactions with a decrease of hydroxyl groups.

4. Cellulose is more resistant to heat, which is attributable mainly to the crystalline fraction. Cellulose crystallinity increases due to degradation of amorphous cellulose.

5. In lignin polycondensation reactions with other cell wall components, resulting in further crosslinking, contribute to an apparent increase in lignin content. The cleavage of the ether linkages, especially $\beta-\mathrm{O}-4$, leads to the formation of free phenolic hydroxyl groups and $\alpha$ - and $\beta$-carbonyl groups, which are responsible for crosslinking via formation of methylenic bridges. The methoxyl content decreases and the new reactive sites on the aromatic ring can lead to further condensation reactions.

6. Extractives are degraded or leave the wood at the same time that new extractable compounds emerge from wood degradation.

7. The reasons for the decrease of the equilibrium moisture are as follows: There is less water absorbed by the cell walls as a result of chemical change with a decrease of hydroxyl groups; there is enhanced inaccessibility of cellulose hydroxyl groups to water molecules due to the increase of cellulose crystallinity; and cross-linking occurs in lignin.

8. Dimensional stability increases due to cross-linking in lignin, due to the destruction of several hydroxyl groups, and due to decreased affinity with water in the case of treated wood. The reason for the improvement cannot be due to the cross linkages because treated wood shrinks in organic solvents such as pyridine or DMSO, as has been reported.

9. Heat treatment improves wood durability, increasing the resistance to rot, except in contact with soil, and slightly to weathering and insects, but it has little effect on termite resistance. Several reasons for the improvement of rot resistance have been reported: the transformation of hemicelluloses, which change from hydrophilic and easily digestible to hydrophobic molecules, and the fungal enzymatic systems do not recognize the substratum, the lower fiber saturation point which, by itself, leads to a better resistance against biological degradation, and there are changes in the external conditions affecting the microenvironment that affect the decay mechanism of heattreated wood. It is also mentioned that there might be an estherification of cellulose due to the acetic acid released by the degradation of hemicelluloses.

10. Heat treatment affects the anatomical structure of wood, but the effects depend on the wood species and on the process conditions used. Tangential and radial cracks, deformation on libriform fibres and collapse of vessels have been reported. 
11. The downside of the treatment is the degradation of mechanical properties. The effect on MOE is small, whereas static and dynamic bending strength and tensile strength decrease. Brittleness of wood increases with the deterioration of fracture properties due to the loss of amorphous polysaccharides. The degradation of hemicelluloses has been identified as the major factor for the loss of mechanical strength, but also the crystallization of amorphous cellulose might play an important role. Polycondensation reactions of lignin, resulting in cross-linking, have been mentioned as having a positive impact mainly on longitudinal direction.

12. Wood becomes darker, wettability and thermal conductivity decrease, and finishing and the gluing process need special attention.

13. An effective quality control measurement is still under development for use with treated wood, but it is clear that it must be different from what has been used in the case of untreated wood.

\section{REFERENCES CITED}

Abe, K., and Yamamoto, H. (2006). "Change in mechanical interaction between cellulose microfibril and matrix substance in wood cell wall induced by hygrothermal treatment," J. Wood Sci. 52, 107-110.

Ala-Viikari (2008). "ThermoWood®: Situation report, ThermoWood $\AA$ Concept," In: 5th European TMT-Workshop 2008, Dresden

Alén, R., Kotilainen, R., and Zaman, A. (2002). "Thermochemical behavior of Norway spruce (Picea abies) at 180-225 ${ }^{\circ}$ C," Wood Sci. Technol. 36, 163-171.

Andersson, S., Serimaa, R., Väänänen, T., Paakkari, T., Jämsä, S., and Viitaniemi, P. (2005). "X-ray scattering studies of thermally modified Scots pine (Pinus sylvestris L.)," Holzforschung 59, 422-427.

Ayadi, N., Lejeune, F., Charrier, F., Charrier, B., and Merlin, A. (2003). "Color stability of heat-treated wood during artificial weathering," Holz Roh-Werkst. 61, 221-226.

Bekhta, P., and Niemz, P. (2003). "Effect of high temperature on the change in color, dimensional Stability and mechanical properties of spruce wood," Holzforschung 57, 539-546.

Bengtsson, C., Jermer, J., and Brem, F. (2002). "Bending strength of heat-treated spruce and pine timber," In: International Research Group Wood Pre, Section 4-Processes, $\mathrm{N}^{\mathrm{o}}$ IRG/WP 02-40242.

Bengtsson, C., Jermer, J., and Clang, A. (2003). "Glulam of heat-treated wood Delamination test," In: Abstracts of the First European Conference on Wood Modification, Ghent, Belgium.

Bhuiyan, T., and Hirai, N. (2000). "Changes of crystallinity in wood cellulose by heat treatment under dried and moist conditions," J. Wood Sci. 46, 431-436.

Bhuiyan, T., and Hirai, N. (2005). "Study of crystalline behaviour of heat-treated wood cellulose during treatments in water," J. Wood Sci. 51, 42-47.

Boonstra, M. (2008). "A two-stage thermal modification of wood" Ph.D. Thesis in Applied Biological Sciences: Soil and Forest management. Henry Poincaré University-Nancy, France. 
Boonstra, M., and Blomberg, J. (2007). "Semi-isostatic densification of heat-treated radiata pine," Wood Sci. Technol. 41, 607-617.

Boonstra, M., and Tjeerdsma, B. (2006). "Chemical analysis of heat-treated softwoods," Holz Roh-Werkst. 64, 204-211.

Boonstra, M., Pizzi., A., and Rigolet, S. (2006c). "Correlation of 13C NMR analysis with fungal decay tests of polymeric structural wood constituents. I. Basidiomycetes," J. Appl. Polymer Sci.101, 2639-2649.

Boonstra, M., Pizzi., A., and Rigolet, S. (2006d). "Correlation of 13C NMR analysis with fungal decay tests of polymeric structural wood constituents. II. Ground contact tests," J. Appl. Polymer Sci.102, 616-622.

Boonstra, M., Rijsdijk, J., Sander, C., Kegel, E., Tjeerdsma, B., Militz, H., Van Acker, J. and Stevens, M. (2006a). "Physical aspects of heat-treated wood. Part 1. Softwoods," Maderas. Ciencia y tecnología. 8, 193-208.

Boonstra, M., Rijsdijk, J., Sander, C., Kegel, E., Tjeerdsma, B., Militz, H., Van Acker, J., and Stevens, M. (2006b). "Physical aspects of heat-treated wood. Part 1.

Hardwoods," Maderas. Ciencia y tecnología. 8, 209-217.

Boonstra, M., Tjeerdsma, B., and Groeneveld, H. (1998). "Thermal Modification of NonDurable Wood Species. 1. The Plato technology: thermal modification of wood," International Research Group Wood Pre, Section 4 - Processes. 29 Annual Meeting, Maastricht, June 14 - 19, 13 p.

Boonstra, M., Van Acker, J, Kegel, E., and Stevens, M. (2007c). "Optimisation of a twostage heat treatment process. Durability aspects. Wood Sci. Technol. 41(1), 31-57.

Boonstra, M., Van Acker, J, Tjeerdsma, B., and Kegel, E. (2007a). "Strength properties of thermally modified softwoods and its relation to polymeric structural wood constituents," Ann. Forest Sci. 64, 679-690.

Boonstra, M., Van Acker, J., and Kegel, E. (2007b). "The effect of a two-stage heat treatment process on the mechanical properties of full construction timber," Wood Mater. Sci. Eng. 2(3-4), 138-146.

Bourgois, J., and Guyonnet, R. (1988). "Characterisation and analysis of torrefied wood," Wood Sci. Technol. 22, 143-155.

Bourgois, J., Bartholin, M., and Guyonnet, R. (1989). "Thermal treatment of wood: Analysis of the obtained product," Wood Sci. Technol. 23, 303-310.

Brischke, C., Welzbacher, C., Brandt, K., and Rapp, A. (2007). "Quality control of thermally modified timber: Interrelationship between heat treatment intensities and CIE L*a*b* color data on homogenized wood samples," Holzforschung. 61, 19-22.

Burmester, A. (1973). "Einfluss einer Wärme-Druck-Behandlung haldtrockenen Holzes auf seine Formbeständigkeit," Holz Roh-Werkst. 31, 237-243

Burmester, A. (1975). “Zur Dimensionsstabilisierung von Holz,” Holz Roh-Werkst. 33, 333-335

Burmester, A. (1973). "Investigation on the dimensional stabilization of wood, Bundesanstalt für Materialprüfung," Berlin-Dahlem, 50-56.

D'Jakonov, K., and Konepleva, T. (1967). "Moisture absorption by Scots Pine wood after heat treatment, Lesn. Z," Arhangel'sk 10(1), 112-114.

Dirol, D., and Guyonnet, R. (1993). "Durability by rectification process," In: International Research Group Wood Pre, Section 4-Processes, No IRG/WP 93-40015. 
Dwianto, W., Tanaka, F., Inoue, M., and Norimoto, M. (1996). "Crystallinity changes of wood by heat or steam treatment," Wood Res. 83, 47-49.

Edvarsden, K., and Sandland, K. (1999). "Increased drying temperature - Its influence on the dimensional stability of wood," Holz Roh-Werkst. 57, 207-209.

EN-350-1 (1994). "Durability of wood and wood-based products. Natural durability of solid wood. Guide to the principles of testing and classification of natural durability of wood."

Epmeier, H., Bengtsson, C., and Westin, M. (2001). "Effect of acetylation and heat treatment on dimensional stability and MOE of spruce timber," In: Proceedings for the First Conference of the European Society for Wood Mechanics, Abril 19-21 2001, Lausanne, Switzerland.

Esteves, B. (2006). Technological Improvement of Portuguese Woods by Heat Modification, Ph.D. Thesis in Environmental Engineering. School of Agronomy. Technical University of Lisbon. In Portuguese.

Esteves, B., and Pereira, H (2008). "Quality assessment of heat-treated wood by NIR spectroscopy," Holz Roh-Werkst, accepted for publication. DOI: 10.1007/s00107008-0262-4.

Esteves, B. M., Domingos, I. J., and Pereira, H. M. (2008a). "Pine wood modification by heat treatment in air," BioRes. 3(1), 142-154.

Esteves, B., Domingos, I., and Pereira, H. (2007a). "Improvement of technological quality of eucalypt wood by heat treatment in air at $170-200^{\circ} \mathrm{C}$, " For. Prod. J. 57 $(1 / 2), 47-52$.

Esteves, B., Graça, J., and Pereira, H. (2008b). "Extractive composition and summative chemical analysis of thermally treated eucalypt wood," Holzforschung, 62, 344-351. DOI 10.1515/HF.2008.057.

Esteves, B., Velez Marques, A., Domingos, I., and Pereira, H. (2008c). "Heat induced colour changes of pine (Pinus pinaster) and eucalypt (Eucalyptus globulus) wood," Wood Sci. Technol. 42(5) 369-384. DOI : 10.1007/s00226-007-0157-2.

Esteves, B., Velez Marques, A., Domingos, I., and Pereira, H. (2007b). "Influence of steam heating on the properties of pine (Pinus pinaster) and eucalypt (Eucalyptus globulus) wood," Wood Sci. Technol. 41,193-207. DOI: 10.1007/s00226-006-0099-0.

Fengel, D. (1966a). "On the changes of the wood and its components within the temperature range up to $200^{\circ} \mathrm{C}$ - Part 1," Holz Roh-Werkst. 24, 9-14.

Fengel, D. (1966b). "On the changes of the wood and its components within the temperature range up to $200^{\circ} \mathrm{C}$ - Part 2," Holz Roh-Werkst. 24, 98-109.

Fengel, D., and Wegener, G. (1989). Wood Chemistry Ultrastructure Reactions, Walter de Gruyter.

Filló, Z., and Peres, T. (1970). "Holztechnologie 11," 270-273, Cited In :Fengel and Wegener (1989).

Follrich, J., Muller, U., and Gindl, W. (2006). "Effects of thermal modification on the adhesion between spruce wood (Picea abies Karst.) and a thermoplastic polymer," Holz Roh-Werkst. 64, 373-376.

Gerardin, P., Petric, M., Petrissans, M., Lambert, J., and Ehrhrardt, J. (2007). "Evolution of wood surface free energy after heat treatment," Polymer Degrad. Stabil. 92, 653657. 
Giebeler, E. (1983). “Dimensionsstabilisierung von Holz durch eine Feuchte/Wärme/ Druck-Behandlung," Holz Roh-Werkst. 41, 87-94.

González-Peña, M., Breese, M., and Hill, C. (2004). "Hygroscopicity in Heat-Treated Wood: Effect of extractives," In: International Conference on Environmentally Compatible Forest Products (ICECFOP) 22-24 September 2004. pp. 105-119.

Goroyias, G., and Hale, M. (2002). "Heat treatment of wood strands for OSB production: Effect on the mechanical properties, water absorption and dimensional stability," International Research Group Wood Pre, Section 4-Processes, No IRG/WP 02-40238.

Gosselink, R., Krosse, A., Van der Putten, J., Van der Kolk, J. Klerk-Engels, B., and Dam, J. (2004). "Wood preservation by low-temperature carbonization," Ind. Crop. Prod. 19, 3-12.

Graf, N., Haas, W., and Böchzelt, H. (2003). "Characterisation of gaseous emissions from a small-size industrial plant for thermal wood modification by GC/MS," In: Abstracts of the First European Conference on Wood Modification, Ghent, Belgium.

Graf, N., Wagner, S., Begander, U., Trinkaus, P., and Boechzelt, H. (2005). "Gaseous emissions from thermal wood modification as a source for fine chemicals recovery," Joanneum Research GmbH.

Gromov, V., Khrol, Y., and Degina, R. (1972). Zb. Pr. Drev. Fak. Vys. Sk. Les. Drew. Zvolene Cited In: Fengel and Wegener (1989).

Hakkou, M., Pétrissans, M., El Bakali, I., Gérardin, P., and Zoulalian, A. (2003). "Evolution of wood hydrophobic properties during heat treatment," In: Abstracts of the First European Conference on Wood Modification, Ghent, Belgium.

Hakkou, M., Pétrissans, M., Gérardin, P., and Zoulalian, A. (2006). "Investigation of the reasons for fungal durability of heat-treated beech wood," Polymer Degrad. Stabill. 91, 393-397.

Hakkou, M., Pétrissans, M., Zoulalian, A., and Gérardin, P. (2005). "Investigation of wood wettability changes during heat treatment on the basis of chemical analysis," Polymer Degrad. Stabil. 89, 1-5.

Hietala, S., Maunu, S., Sundholm, F., Jämsä, S., and Viitaniemi, P. (2002). "Structure of thermally modified wood studied by liquid state NMR measurements," Holzforschung 56, 522-528.

Hill, C. (2006). Wood Modification-Chemical, Thermal and Other Processes, Wiley Series in Renewable Resources, John Wiley \& Sons, Ldt.

Hillis, W. (1984). "High temperature and chemical effects on wood stability. Part 1. General considerations," Wood Sci. Technol.18, 281-293.

Hinterstoisser, B., Schwanninger, M., Stefke, B., Stingl, R., and Patzelt, M. (2003). "Surface analyses of chemically and thermally modified wood by FT-NIR," In Abstracts of the First European Conference on Wood Modification, Ghent, Belgium.

Inoue, M., Norimoto, M., Tanahashi, M., and Rowell, R. (1993). "Steam or heat fixation of compressed wood," Wood Fiber Sci. 25(3), 224-235.

Jämsä, S., and Viitaniemi, P. (2001). "Heat treatment of wood - Better durability without chemicals," In: Proceedings of special seminar held in Antibes, France.

Jämsä, S., Ahola, P., and Viitaniemi, P. (2000). "Long-term natural weathering of coated Thermowood," Pigment Resin Technol. 29(2), 68-74. 
Johansson, D., and Moren, T. (2006). "The potential of colour measurement for strength prediction of thermally treated wood," Holz Roh-Werkst. 64, 104-110.

Kamdem, D., Pizzi, A., and Triboulot, M. (2000). "Heat-treated timber: Potentially toxic byproducts presence and extent of wood cell wall degradation," Holz Roh-Werkst. 58, 253-257.

Kamdem, D., Pizzi, A., and Jermannaud, A. (2002). "Durability of heat-treated wood," Holz Roh-Werkst. 60, 1-6.

Kim, G., Yun, K., and Kim, J. (1998). "Effect of heat treatment on the decay resistance and the bending properties of radiata pine sapwood," Material und Organismen 32(2), 101-108.

Kocaefe, D., Poncsak, S., and Boluk, Y. (2008a). "Effect of thermal treatment on the chemical composition and mechanical properties of birch and aspen," Biores. 3(2), 517-537.

Kocaefe, D., Poncsak, S., Dore, G., and Younsi, R. (2008b). "Effect of heat treatment on the wettability of white ash and soft maple by water" Holz Roh-Werkst. in press 2008.

Kocaefe, D., Younsi, R., Chaudry, B., and Kocaefe, Y. (2006). "Modelling of heat and mass transfer during high temperature treatment of aspen” Wood Sci. Technol. 40, 371-391.

Kollmann, F. (1936). Technologie des Holzes und der Holzwerkstoffe, Springer Verlag, Berlin.

Kollmann, F., and Fengel, D. (1965). "Changes in the chemical composition of wood by heat treatment," Holz Roh-Werkst. 12, 461-468.

Kollmann, F., and Schneider, A. (1963). "On the sorption behaviour of heat stabilized wood," Holz Roh-Werkst. 21(3), 77-85.

Korkut, D., and Guller, B. (2008). "The effects of heat treatment on physical properties and Surface roughness of Red-bud maple (Acer trautvetteri Medw.) wood," Bioresour. Technol. 99, 2846-2851.

Korkut, S., Akgü, M., and Dündar, T. (2008a). "The effects of heat treatment on some technological properties of Scots pine (Pinus sylvestris L.) wood," Bioresour. Technol. 99, 1861-1868.

Korkut, S., Kök, M., Korkut, D., and Gürleyen T. (2008b). "The effects of heat treatment on technological properties in Red-bud maple (Acer trautvetteri Medw.) wood," Bioresour. Technol. 99, 1538-1543.

Kotilainen, R., Toivannen, T., and Alén, R. (2000). "FTIR monitoring of chemical changes in softwood during heating," J. Wood Chem. Technol. 20(3), 307-320.

Kubojima, Y., Okano, T., and Ohta, M. (1998). "Vibrational properties of Sitka spruce heat-treated in nitrogen gas," J. Wood Sci. 44, 73-77.

Kubojima, Y., Okano, T., and Ohta, M. (2000a). "Vibrational properties of heat-treated green wood," J. Wood Sci. 46, 63-67.

Kubojima, Y., Okano, T., and Ohta, M. (2000b). "Bending strength of heat-treated wood," J. Wood Sci. 46, 8-15.

Leithoff, H., and Peek R. (2001). "Heat treatment of bamboo," International Research Group Wood Pre, Section 4-Processes, N IRG/WP 01-40216. 
Manninen, A., Pasanen, P., and Holopainen J. (2002). "Comparing the VOC emissions between air-dried and heat-treated Scots pine wood," Atmosph Environ. 36, 17631768.

Mayes, D., and Oksanen, O. (2002). Thermowood Handbook, Thermowood, Finnforest, Stora.

Mazela, B., Zakrzewski, R., Grzeskowiak, W., Cofta, G., and Bartkowiak, M. (2003). "Preliminary research on the biological resistance of thermaly modified wood," In: Abstracts of the First European Conference on Wood Modification, Ghent, Belgium.

Mburu, F., Dumarçay, S., Bocquet, J. F., Pétrissans, M. and Gérardin, P. (2008). "Effect of chemical modifications caused by heat treatment on mechanical properties of Grevillea robusta wood," Polymer Degrad. Stabil. 93, 401-405.

McDonald, A., Fernandez, M., and Kreber, B. (1997). "Chemical and UV-VIS spectroscopic study on kiln brown stain formation in Radiata pine," In: 9th International Symposium of Wood and Pulping Chemistry, Montreal, Canada 70, 1-5.

Metsä-Kortelainen, S., Antikainen, T., and Viitaniemi, P. (2006). "The water absorption of sapwood and heartwood of Scots pine and Norway spruce heat-treated at $170^{\circ} \mathrm{C}$, $190^{\circ} \mathrm{C}, 210^{\circ} \mathrm{C}$ and $230^{\circ} \mathrm{C}$," Holz Roh-Werkst. 64(3), 192-197.

Militz, H. (2002). "Heat treatment of wood: European processes and their background," In: International Research Group Wood Pre, Section 4-Processes, N IRG/WP 0240241.

Mitchell, P. (1988). "Irreversible property changes of small Loblolly Pine specimens heated in air, nitrogen, or oxygen," Wood Fiber Sci. 20(3), 320-333.

Mitsui, K., Inagaki, T., and Tsuchikawa, S.(2008). "Monitoring of hydroxyl groups in wood during heat treatment using NIR spectroscopy," Biomacromolecules 9, 286288.

Mitsui, K., Murata, A., and Tolvaj L. (2004). "Changes in the properties of lightirradiated wood with heat treatment: Part 3. Monitoring by DRIFT spectroscopy," Holz Roh-Werkst. 62, 164-168.

Mitsui, K., Murata, A., Kohara, M., and Tsuchikawa, S. (2003). "Colour modification of wood by light-irradiation and heat treatment," In: Abstracts of the First European Conference on Wood Modification, Belgium.

Mitsui, K., Takada, H., Sugiyama, M., and Hasegawa, R. (2001). "Changes in the properties of light-irradiated wood with heat treatment: Part 1. Effect of treatment conditions on the change in color," Holzforschung 55, 601-605.

Morsig, N. (2000). "Densification of wood - The influence of hygrothermal treatment on compression of beech perpendicular to the grain," Institut for Bcerende Konstruktioner og Materialer. Department of structural engineering and materials. Technical University of Denmark 79.

Nakano, T., and Miyazaki, J. (2003). "Surface fractal dimensionality and hygroscopicity for heated wood," Holzforschung 57, 289-294.

Nguila Inari, G., Petrissans, M., Lambert, J., Ehrhard, J., and Gerardin, P. (2006). "XPS characterization of wood chemical composition after heat-treatment," Surface and interface analysis 38(10), 1336-1342. 
Nikolov, S., and Encev, E. (1967). "Effect of heat treatment on the sorption dynamics of Beech wood,” Nauc. Trud. Lesoteh. Inst., Sofija (Ser. meh. Tehn. Darv.), No. 14(3), 71-77.

Noack, D. (1969). “Über die Heisswasserbehandlung von Rotbuchenholz im Temperaturbereich von 100 bis $180^{\circ} \mathrm{C}$," Holz. Holzverwert. 21(5), 118-124.

Nunes, L., Nobre, T., and Rapp, A. (2004). "Thermally modified wood in choice tests with subterranean termites," COST E37, Reinbeck.

Nuopponen, M., Vuorinen, T., Jämsä, S., and Viitaniemi, P. (2003). "The effects of heat treatment on the behaviour of extractives in softwood studied by FTIR spectroscopic methods," Wood Sci. Technol. 37, 109-115.

Nuopponen, M., Vuorinen, T., Jamsä, S., and Viitaniemi, P. (2004). “Thermal modifications in softwood studied by FT-IR and UV resonance Raman spectroscopies," J. Wood Chem. Technol. 24, 13-26.

Patzelt, M., Emsenhuber, G., and Stingl, R. (2003). "Color measurement as means of quality control of thermally treated wood," In: Abstracts of the First European Conference on Wood Modification, Ghent, Belgium.

Paul., W., Ohlmeyer, M., Leithoff, H., Boonstra, M., and Pizzi, A. (2006). “Optimising the properties of OSB by a one-step heat pre-treatment process," Holz Roh-Werkst. 64, 227-234.

Pecina, H., and Paprzycki, O. (1988). "Wechselbeziehungen zwischen der Temperaturbehandlung des Holzes und seiner Benetzbarkeit," Holz. Holzverwert 40(1), 5-8.

Peters, J., Fischer, K., and Fisher, S. (2008). "Characterization of emissions from thermally modified wood and their reduction by chemical treatment," BioRes. 3(2), 491-502.

Petric, M., Knehtl, B., Krause, A., Militz, H., Pavlic, M., Pétrissans, M., Rapp, A., Tomazic, M., Welzbacher, C., and Gérardin, P. (2007). "Wettability of waterbourne coatings on chemically and thermally modified pine wood," J. Coat. Technol. Res. 4(2), 203-206.

Pétrissans, M., Philippe, G., El Bakali, I., and Serraj, M. (2003). "Wettability of heattreated Wood," Holzforschung 57, 301-307.

Phuong, L., Shida, S., and Saito Y. (2007). "Effects of heat treatment on brittleness of Styrax tonkinensis wood," J. Wood Sci. 53, 181-186.

Pincelli, A., Brito, J., and Corrente, J. (2002). "Avaliação da termorretificação sobre a colagem na madeira de Eucalyptus saligna e Pinus caribaea," Scientia Forestalis 61, 122-132.

Poncsak, S., Kocaefe, D., Bouazara, M., and Pichette, A. (2006). "Effect of high temperature treatment on the mechanical properties of birch (Betula papyrifera)," Wood Sci. Technol. 40, 647-663.

Potutkin, G., and Shirayena, L. (1975). "Changes in chemical components of wood during high temperature drying," Izv. Vyssh. Uchebn.Zaved. Lesn. Zh. 18,127-129.

Rapp, A. (2001). "Review on heat treatments of wood, COST ACTION E22Environmental optimisation of wood protection," Proceedings of Special Seminar in Antibes, França. 
Rapp, A., Brischke, C., and Welzbacher, C. (2006). "Interrelationship between the severity of heat treatments and sieve fractions after impact ball milling: A mechanical test for quality control of thermally modified wood," Holzforschung 60, 64-70.

Reiterer, A., and Sinn, G. (2002). "Fracture behaviour of modified spruce wood: A study using linear and non linear fracture mechanics," Holzforschung 56, 191-198.

Repellin, V., and Guyonnet, R. (2003). "Evaluation of heat-treated beech by nondestructive testing," In: Abstracts of the First European Conference on Wood Modification, Ghent, Belgium.

Repellin, V., and Guyonnet, R. (2005). "Evaluation of heat-treated wood swelling by differential scanning calorimetry in relation to chemical composition," Holzforschung 59, 28-34.

Roffael, E., and Schaller, K. (1971). "The influence of thermal treatment on cellulose" Holz Roh-Werkst. 29(7), 275-278.

Rousset P., Perré, P., and Girard, P. (2004). "Modification of mass transfer properties in poplar wood (P.robusta) after a thermal treatment at high temperature," Holz RohWerkst. 62(2), 113-119.

Rusche, H. (1973a). "Thermal degradation of wood at temperatures up to $200^{\circ} \mathrm{C}$ : Part I," Holz Roh-Werkst. 31, 273-281.

Rusche, H. (1973b). "Thermal degradation of wood at temperatures up to $200^{\circ} \mathrm{C}$ : Part II," Holz Roh-Werkst. 31, 307-312.

Sailer, M., Rapp, A., and Leithoff, H. (2000). "Improved resistance of Scots pine and spruce by application of an oil-heat treatment," In: International Research Group Wood Pre, Section 4-Processes, N IRG/WP 00-40162.

Santos, J. (2000). "Mechanical behaviour of Eucalyptus wood modified by heat," Wood Sci. Technol. 34, 39-43.

Schwanninger, M., Hinterstoisser, B., Gierlinger, N., Wimmer, R., and Hanger, J. (2004). "Application of Fourier Transform Near Infrared Spectroscopy (FT-NIR) to thermally modified wood," Holz Roh-Werkst. 62 (6), 483-485.

Seborg, R., Millet, M., and Stamm, A., (1945). "Heat-stabilized compressed wood. Staypack," Mech. Eng. 67, 25-31.

Seborg., R., Tarkow, H., and Stamm, A. (1953). "Effect of heat upon the dimensional stabilisation of wood," J. For. Prod. Res. Soc. 3(9), 59-67.

Sehlstedt-Persson,_M. (2003). "Colour responses to heat treatment of extractives and sap from pine and spruce," 8th International IUFRO Wood Drying Conference, Brasov, Romania, 459-464.

Sernek, M., Boonstra, M., Pizzi, A. Despres, A., and Gerardin, P. (2008). "Bonding performance of heat-treated wood with structural adhesives," Holz Roh-Werkst. 66(3), 173-180.

Shi, J., Kocaefe, D., and Zhang J. (2007). "Mechanical behaviour of Quebecwood species heat-treated using ThermoWood process," Holz Roh-Werkst 65, 255-259.

Sivonen, H., Maunu, S., Sundholm, F., Jämsä, S., and Viitaniemi, P. (2002). "Magnetic resonance studies of thermally modified wood," Holzforschung. 56, 648-654.

Stamm, A., Burr, H., and Kline, A. (1946). "Stayb-wood-A heat stabilized wood," Ind. Eng. Chem. 38(6), 630-634. 
Stamm, A., and Hansen, L. (1937). "Minimizing wood shrinkage and swelling: Effect of heating in various gases," Ind. Eng. Chem. 29(7), 831-833.

Sundqvist, B. (2004). "Colour changes and acid formation in wood during heating," Doctoral Thesis. Lulea University of Technology.

Sundqvist, B., and Morén, T. (2002). "The influence of wood polymers and extractives on wood colour induced by hydrothermal treatment," Holz Roh-Werkst 60, 375-376.

Sundqvist, B., Karlsson, O., and Westermark, U. (2006). "Determination of formic-acid and acetic acid concentrations formed during hydrothermal treatment of birch wood and its relation to colour, strength and hardness," Wood Sci. Technol. 40, 549-561.

Syrjänen, T., and Kangas, E. (2000). "Heat-treated timber in Finland," International Research Group Wood Pre, Section 4-Processes, No IRG/WP 00-40158.

Taniguschi, T., and Nakato, K. (1966). "Effects of heat treatment on the fine structure of soft wood," Bull. Kyoto Univ. For.

Tiemann, H. (1920). Effect of Different Methods of Drying on the Strength and Hygroscopicity of Wood. $3^{\text {rd }}$ Ed. "The kiln drying of lumber," Chap. 11, J. P. Lippincott Co.

Tjeerdsma, B., and Militz, H. (2005). "Chemical changes in hydroheat wood: FTIR analysis of combined hydroheat and dry heat-treated wood," Holz Roh-Werkst. 63, 102-111.

Tjeerdsma, B., Boonstra, M., and Militz, H. (1998b). "Thermal modification of nondurable wood species. Part 2. Improved wood properties of thermally treated wood," International Research Group on Wood Pre., Document no. IRG/WP 98- 40124.

Tjeerdsma, B., Boonstra, M., Pizzi, A., Tekely, P., and Militz, H. (1998a). "Characterisation of thermaly modified wood: Molecular reasons for wood performance improvement," Holz Roh-Werkst 56, 149-153.

Tjeerdsma, B., Stevens, M., and Militz, H. (2000). "Durability aspects of hydrothermal treated wood," International Research Group Wood Pre, Section 4-Processes, No IRG/WP 00-40160.

Tjeerdsma, B., Stevens, M., Militz, H., and Van Acker, J. (2002). "Effect of process conditions on moisture content and decay resistance of hydro-thermally treated wood," Holz. Holzverwert. 5, 94-99.

Troya, M., and Navarrete, A. (1994). "Study of the degradation of retified wood through ultrasonic and gravimetric techniques," International Research Group Wood Pre, Section 4-Processes, No IRG/WP 94-40030.

Unsal, O., and Ayrilmis, N. (2005). "Variations in compression strength and surface roughness of heat-treated Turkish river red gum," J. Wood Sci. 51, 405-409.

Vernois, M. (2000). "Heat treatment of wood in France-State of the art," Centre Technique du Bois et de l'Ameublement, Paris, França.

Viitaniemi, P., Jämsä, S., and Viitanen, H. (1997). "Method for improving biodegradation resistance and dimensional stability of cellulosic products," United States Patent $\mathrm{N}^{\mathrm{o}}$ 5678324 (US005678324).

Vital, B., Lucia, R., Della, R., and Euclides, R. (1983). "Effect of heating on some properties of Eucalyptus saligna wood," Revista-Árvore 7(2), 136-146. 
Weiland, J., and Guyonnet, R. (2003). "Study of chemical modifications and fungi degradation of thermally modified wood using DRIFT spectroscopy," Holz RohWerkst. 61, 216-220.

Welzbacher, C., and Rapp, O. (2002). "Comparison of thermally modified wood originating from four industrial scale processes- durability," International Research Group Wood Pre, Section 4-Processes, N IRG/WP 02-40229.

Westin, M., Rapp, A., and Nilsson, T. (2006). "Field test of resistance of modified wood to marine borers," Wood Mater. Sci. Eng.. 1(1), 34-38.

Wikberg, H., and Maunu, S. (2004). "Characterisation of thermally modified hard- and softwoods by 13C CPMAS NMR," Carbohydr Polym. 58, 461-466.

Winandy, J., and Lebow, P. (2001). "Modeling strength loss in wood by chemical composition. Part I. An individual component model for southern pine," Wood Fiber Sci. 33(2), 239-254.

Windeisen, E., Strobel, C., and Wegener, G. (2007). "Chemical changes during the production of thermo-treated beech wood," Wood Sci. Technol. 41, 523-536.

Yildiz, S. (2002a). "Effects of heat treatment on water repellence and anti-swelling efficiency of beech wood," In: International Research Group Wood Pre, Section 4Processes, $N^{\circ}$ IRG/WP 02-40223.

Yildiz, S. (2002b). "Physical, mechanical, technological and chemical properties of beech and spruce wood treated by heating," $\mathrm{PhD}$ dissertation, Karadeniz Tech. Univ., Trabzon, Turkey.

Yildiz, S., and Gümüskaya, E. (2007). "The effects of thermal modification on crystalline structure of cellulose in soft and hardwood," Building Environ. 42, 62-67.

Yildiz, S., Gezer, D., and Yildiz, U. (2006). "Mechanical and chemical behavior of spruce wood modified by heat," Building Environ. 41, 1762-1766.

Younsi, R., Kocaefe, D., and Kocaefe Y. (2006a). "Three-dimensional simulation of heat and moisture transfer in wood," Appl. Therm. Eng. 26(11-12), 1274-1285.

Younsi, R., Kocaefe, D., Poncsak, S., and Kocaefe Y. (2006b). "Thermal modeling of the high temperature treatment of wood based on Luikov's approach," Int. J. Energy Res. 30(9), 699-71.

Younsi, R., Kocaefe, D., Poncsak, S., and Kocaefe Y. (2007). “Computational modelling of heat and mass transfer during the high-temperature heat treatment of wood," Appl. Therm. Eng. 27, 1424-1431.

Zaman, A., Alen, R., and Kotilainen, R. (2000). "Heat behavior of Pinus sylvestris and Betula pendula at 200-230 ${ }^{\circ}$," Wood Fiber Sci. 32(2), 138-143.

Article received: Sept. 16, 2008; Peer review completed: Oct. 21, 2008; Revised version received and accepted: Dec. 3, 2008; Published: Dec. 4, 2008; Page numbers applied: Feb. 2009. 